\title{
Discovery and Characterization of a Thermostable Esterase from an 0il Reservoir Metagenome
}

\author{
Anna Lewin', Trine Aakvik Strand ${ }^{1,2}$, Tone Haugen', Geir Klinkenberg1, \\ Hans Kristian Kotlar ${ }^{3}$, Svein Valla ${ }^{4}$, Finn Drabløs ${ }^{2}$, Alexander Wentzel ${ }^{1 *}$ \\ ${ }^{1}$ SINTEF Materials and Chemistry, Department of Biotechnology and Nanomedicine, Trondheim, Norway \\ ${ }^{2}$ Department of Cancer Research and Molecular Medicine, Norwegian University of Science and Technology, \\ Trondheim, Norway \\ ${ }^{3}$ Former at Statoil ASA, Ranheim, Norway \\ ${ }^{4}$ Department of Biotechnology, Norwegian University of Science and Technology, Trondheim, Norway \\ Email: *alexander.wentzel@sintef.no
}

Received 11 April 2016; accepted 24 June 2016; published 28 June 2016

Copyright (C) 2016 by authors and Scientific Research Publishing Inc.

This work is licensed under the Creative Commons Attribution International License (CC BY).

http://creativecommons.org/licenses/by/4.0/

c) (i) Open Access

\begin{abstract}
With the aim of identifying novel thermostable esterases, comprehensive sequence databases and cloned fosmid libraries of metagenomes derived from an offshore oil reservoir on the Norwegian Continental Shelf were screened for enzyme candidates using both sequence-and function-based screening. From several candidates identified in both approaches, one enzyme discovered by the functional approach was verified as a novel esterase and subjected to a deeper characterization. The enzyme was successfully over-produced in Escherichia coli and was shown to be thermostable up to $90^{\circ} \mathrm{C}$, with the highest esterase activity on short-chain ester substrates and with tolerance to solvents and metal ions. The fact that the thermostable enzyme was solely found by functional screening of the oil reservoir metagenomes illustrates the importance of this approach as a complement to purely sequence-based screening, in which the enzyme candidate was not detected. In addition, this example indicates the large potential of deep-sub-surface oil reservoir metagenomes as a source of novel, thermostable enzymes of potential relevance for industrial applications.
\end{abstract}

\section{Keywords}

Metagenomics, Enzyme Discovery, Thermostable, Esterase

\footnotetext{
${ }^{*}$ Corresponding author.
}

How to cite this paper: Lewin, A., Strand, T.A., Haugen, T., Klinkenberg, G., Kotlar, H.K., Valla, S., Drabløs, F. and Wentzel, A. (2016) Discovery and Characterization of a Thermostable Esterase from an Oil Reservoir Metagenome. Advances in Enzyme Research, 4, 68-86. HTTP://DX.DOI.ORG/10.4236/AER.2016.42008 


\section{Introduction}

The globe provides a large spectrum of environments with very diverse physical and chemical conditions for life to exist [1]. Some of these are considered extreme, providing for example high or low temperatures, $\mathrm{pH}$ or salt concentrations, or high pressure, radiation, as well as different combinations thereof. Deep sub-surface offshore oil reservoirs are poly-extreme environments due to a combination of high temperature, high pressure, high salinity, nutrient limitations, as well as the presence of toxic compounds like heavy metals and organic solvents [2]. Microorganisms populating these environments are generally considered (poly) extremophiles, attributing several unusual and interesting traits [3]. However, studies of these microbes are limited by difficulties in accessing relevant oil reservoirs, as well as technical challenges in representative oil reservoir sampling [4] [5]. Due to their nature, oil reservoir microorganisms with their special adaptations are potential high value targets for the discovery of useful biocatalysts for industrial processes [6]-[8]. By also covering the genetic information of the vast uncultivable fraction of microorganisms in nature [1] which is particularly pronounced in such special ecological niches, metagenomic libraries are an invaluable source for new discoveries by bioprospecting, using both metagenomic sequence data and cloned metagenomic DNA [9] [10]. Sequence-based bioprospecting using metagenomic DNA sequence databases has benefits in being fast and inexpensive to perform, and is independent of functional expression in a heterologous host and functional assays. However, its dependence on previously described sequence information limits its potential to discover entirely new enzymes. In contrast, function-based screening for activities of interest using cloned metagenomic libraries is capable of discovering novel enzymes based on the function, independent of sequence similarity to previously known genes. It represents therefore a valuable complement to sequence data mining, despite of its dependence on assay methods and vector-host systems for functional gene expression.

Esterases are enzymes with several applications in industrial processes, and novel variants of these providing special properties are still in demand [11]. They are today commercially used e.g. in the food industry, for animal feed and biofuel production, as well as detergents. New candidates with high tolerance to elevated temperature and pressure, stability and activity in organic solvents, and/or special substrate spectra may prove useful in these, or other applications [12]. In the current study, we have screened oil reservoir metagenomes [13] [14] for esterase enzyme candidates using both sequence-based and functional screening, and have subjected one candidate from the functional screening approach to further characterization. Our results document oil reservoir metagenomes as a valuable source of novel thermostable enzymes of potential industrial relevance.

\section{Materials and Methods}

\subsection{Sample Collection, DNA Isolation and Fosmid Library Generation}

Oil reservoir samples were collected and processed as described earlier [13] [14]. Metagenomic DNA was isolated [14] from the sample material and used for direct high throughput sequencing (water phases of Wells I and II of [14]), as well as whole genome amplification (WGA) using Qiagen REPLi-g kit according to the manufacturer's protocol (water phase of Well II of [14]) and both water and oil phase of a third, nearby production well (Well III) that, unlike Wells I and II, has experienced seawater breakthrough. Amplified DNA was cloned as fosmid libraries using the pCC1fos fosmid library kit from Epicentre according to the manufacturer's instructions [15]. Library clones of each sample were selected for on square (215 ml volume) LB agar plates containing $12.5 \mu \mathrm{g} / \mathrm{ml}$ chloramphenicol, pooled and stored in $25 \%$ glycerol at $-80^{\circ} \mathrm{C}$. Based on colony counts, the total library harbors approximately 77,000 independent fosmid clones. Prior to functional screening, library pools from the different samples were again plated onto the same type of selective agar plates (LB-agar $+12.5 \mu \mathrm{g} / \mathrm{ml}$ chloramphenicol), with 350 - $1500 \mathrm{CFU}$ per plate. Proportional to the number of total clones represented in each library, the corresponding number of agar plates and 384 multi-well plates were used for the different samples. In total 20 agar plates were processed; 14 with Well II water phase library clones, 4 with Well III water phase library clones and 2 with Well III oil phase library clones. Correspondingly, 21 individual 384 well plates were inoculated with Well II water phase library clones, 6 plates with Well III water phase clones and 3 plates with Well III oil phase clones. Clones within the well plates were grown in $80 \mu \mathrm{l}$ reduced Hi-YE medium per well containing $12.5 \mu \mathrm{g} / \mathrm{ml}$ chloramphenicol $\left(37^{\circ} \mathrm{C}, 900 \mathrm{rpm}, 85 \%\right.$ humidity, 20 hours), plates were duplicated and then stored at $-80^{\circ} \mathrm{C}$ with $25 \%$ final concentration glycerol. 


\subsection{Sequence Mining}

Twenty Pfam [16] profiles for known lipases and esterases were used as input to tBLASTn searches [17] against ORFs of the metagenomic DNA libraries, using an E-value cutoff of 0.00001 and a minimal overlap of $50 \%$ on the Pfam motif. In addition, ORFs of the metagenomic libraries were classified according to EC numbers using tBLASTn with exemplar sequences derived from the BRENDA database [18].

\subsection{Functional Screening (HTS)}

Approximately 11,520 fosmid clones carrying metagenomic DNA sequences originating from oil reservoir Well II (water phase sample) [14] and Well III (oil and water phase) were screened for lipase and/or esterase activities. Functional screening (schematically described in supplementary Figure S1) was performed using liquid culture extracts in 30 individual 384 well plates. Each of the 30384 well plates of one stored replica set from library construction was used to inoculate 4 individual 96 well plates, in which the clones were grown for 20 hours under the same conditions as described above and subsequently the increase of fosmid copy number induced for 6 hours by addition of arabinose from a $10 \%$ (w/v) stock solution ( $0.01 \%$ final conc.). Cultivation plates were then stored at $-80^{\circ} \mathrm{C}$ until extraction. After thawing, crude cell extracts were prepared by adding $30 \mu \mathrm{l}$ B-PER II (Thermo Scientific, prod\# 89822) to each well, followed by an incubation at $25^{\circ} \mathrm{C}, 700 \mathrm{rpm}, 85 \%$ humidity for 1 hour. Cell debris was pelleted by centrifugation $\left(4000 \mathrm{rpm}, 30\right.$ minutes, $\left.4^{\circ} \mathrm{C}\right)$. Supernatants (extracts) were transferred in duplicates to 384 well plates and used in enzyme assays (Figure S1).

High throughput screening for short-chain esterase activity was performed in 384 well plates by addition of 5 $\mu \mathrm{l}$ crude cell extract to each well containing $40 \mu \mathrm{l}$ reaction mixture $(0.17 \mathrm{mM}$ 4-nitrophenyl acetate substrate (Sigma-Aldrich, no. N8130) in $0.1 \mathrm{M}$ phosphate buffer, pH 8, containing 4.4\% EtOH), shaking of the plates (1600 rpm, $30 \mathrm{~s}$ ) and absorption measurement at $410 \mathrm{~nm}$ immediately and after $100 \mathrm{~min}$ incubation at $37^{\circ} \mathrm{C}$. For screening for long-chain esterase activity, the same procedure was applied, with the exception of the reaction mixture containing $0.17 \mathrm{mM}$ 4-nitrophenyl palmitate (Sigma-Aldrich, no. N2752), 4.4\% EtOH and 1\% Triton $\mathrm{X}-100$ in $0.1 \mathrm{M}$ phosphate buffer, $\mathrm{pH}$ 8, and performing absorption measurements at time points 0,1 and 3 hours after $50^{\circ} \mathrm{C}$ incubation.

\subsection{Analysis of Positive Clones}

Esterase positive clones identified in functional screening were subjected to fosmid isolation using the Promega Wizard Miniprep kit (arabinose induced cultures), and the genes of interest were identified by sequencing of respective fosmid clones and sub-cloning of candidate genes. Gene sequences were analyzed using BLASTx against the NCBI database. Amino acid sequences were analyzed on the Phylogeny.fr web server [19], using T-Coffee [20] for multiple alignment, PhyML [21] for generating the phylogenetic tree (after removing all columns with gaps), and TreeDyn [22] for drawing the tree. Branch support in the phylogenetic tree was estimated by the approximate likelihood ratio test (aLRT) [23]. The multiple alignment was visualized using Jalview [24]. Pairwise comparison of protein sequences was done with pairwise BLAST.

\subsection{Enzyme Production}

The esterase candidate genes were amplified using PCR from the relevant fosmid (primer sequences GGGGCCATGGGAGATAAGGAGGAGGG and GGGGATCCAAAGATAGAGGAGCAGATC for His-tagged enzyme, and sequences ATAAGGAGGAGGGCATATGGCTGA and GGGGATCCAAAGATAGAGGAGCAGATC for non-tagged enzyme), or synthesized as E. coli codon optimized versions (GenScript, Piscataway, NJ, USA) and sub-cloned in expression vector pET16b (with and without hexahistidyl-tag; however, only untagged protein was analyzed as enzyme isolation by heat incubation proved to be feasible). Enzymes were produced in E. coli BL21 (DE3) REPL (codon+) grown in shake flasks in $50 \mathrm{ml} \mathrm{LB}$ containing $100 \mu \mathrm{g} / \mathrm{ml}$ ampicillin. Gene expression was induced at $\mathrm{OD}_{600}=1.0$ using IPTG $\left(0.5 \mathrm{mM}\right.$ final conc.). After continued incubation at $37^{\circ} \mathrm{C}$ until observed $\mathrm{OD}_{600}$ decrease after approx. $7 \mathrm{~h}$, the cultures were harvested by centrifugation (4000 rpm, 15 minutes, 4 ${ }^{\circ} \mathrm{C}$ ) and cell pellets stored at $-20^{\circ} \mathrm{C}$ until extraction. Crude cell extracts were prepared by sonication in $2 \mathrm{ml} 0.1$ $\mathrm{M}$ Tris-HCl buffer, $\mathrm{pH}$ 8, per $1 \mathrm{~g}$ wet weight biomass (flat tip, duty cycle $50 \%$, output control 4; $7 \times 1 \mathrm{~min}$ ). Cell debris was pelleted by centrifugation $\left(20000 \mathrm{xg}, 20 \mathrm{~min}, 4^{\circ} \mathrm{C}\right)$ and supernatant stored at $-20^{\circ} \mathrm{C}$.

Batch cultivation for the production of esterase FS02 was performed in two 3 l Applicon fermentor vessels 
using $1.8 \mathrm{l}$ 3xLB medium (Tryptone $30 \mathrm{~g} / \mathrm{l}$, Yeast extract $15 \mathrm{~g} / \mathrm{l}, \mathrm{NaCl} 10 \mathrm{~g} / \mathrm{l}$ ) each, containing $100 \mu \mathrm{g} / \mathrm{ml}$ ampicillin, with constant airation at $0.25 \mathrm{VVM}(0.45 \mathrm{l} / \mathrm{min})$ and $1000 \mathrm{rpm}$ fixed stirrer speed. The cultivation medium was inoculated with $1.5 \%$ (27 ml) overnight culture (LB, $100 \mu \mathrm{g} / \mathrm{ml}$ ampicillin). Gene expression was induced at $\mathrm{OD}_{600}=4$ using (3 hours cultivation) $0.5 \mathrm{mM}$ IPTG. Cultures were thereafter harvested after 6 hours of induction and thereafter treated as described above to obtain crude cell extracts. Crude cell extracts were heat treated at $65^{\circ} \mathrm{C}$ for 30 minutes, centrifuged at top speed $(13000 \mathrm{x} \mathrm{g})$ in a table top centrifuge for 5 minutes to precipitate denatured host proteins, aliquoted and stored at $-20^{\circ} \mathrm{C}$.

\subsection{Enzyme Characterization}

Verification of lipase activity. Crude cell extracts were used to assess lipase enzyme function using the same assay procedure as applied for esterase screening in multi-well plates, however, up-scaled to $1 \mathrm{ml}$ volume for cuvette measurements. To $880 \mu \mathrm{l}$ master mix $(4.4 \% \mathrm{EtOH}$ and $1 \%$ Triton X-100 in $0.1 \mathrm{M}$ phosphate buffer, $\mathrm{pH}$ 8), $20 \mu$ l substrate solution ( $20 \mathrm{mM}$ 4-nitrophenyl palmitate in acetonitrile) was added, incubated at $37^{\circ} \mathrm{C}$ for 30 s prior to addition of $100 \mu \mathrm{l}$ cell extract and absorbance measurement at $420 \mathrm{~nm}$ every 2 seconds for 4 minutes. End point measurements were performed using the same setup but with measurements after 30, 60 and 120 minutes, with assay and incubations done at $37^{\circ} \mathrm{C}$.

Heat stability. Temperature stability of enzymes was determined by incubating crude extracts at elevated temperatures $\left(65^{\circ} \mathrm{C}-100^{\circ} \mathrm{C}\right)$ for different time periods (15 min - overnight), followed by SDS-PAGE and/or activity assay as described above. Thermal unfolding transition midpoint Tm of the enzyme of interest was analyzed using the Thermal Shift assay from Applied Biosystems on a 7500 rtPCR machine according to the manufacturer's instructions.

pH optimum. The $\mathrm{pH}$ optimum of the enzyme of interest was analyzed by performing the esterase activity assay at $37^{\circ} \mathrm{C}$ as described above but using buffer with different $\mathrm{pH}(0.1 \mathrm{M}$ glycine buffer $\mathrm{pH} 2-3$ and $\mathrm{pH} 9-12$; $0.05 \mathrm{M}$ citrate buffer $\mathrm{pH}$ 5, $0.1 \mathrm{M}$ phosphate buffer $\mathrm{pH} 6$ - 8).

Substrate spectrum. Enzyme activity on a spectrum of commercial ester substrates of different chain lengths (C2-C18; p-nitrophenyl acetate, p-nitrophenyl-butyrate, p-nitrophenyl-decanoate, p-nitrophenyl-myristate, p-nitrophenyl-palmitate and p-nitrophenyl-stearate) was analyzed using the assay procedure describe above.

Effect of selected additives on enzyme activity. Esterase activity in the presence of different additives was assayed as described above using p-nitrophenyl-butyrate as the substrate. Chemicals added were; metal ions (1 $\mathrm{mM}$ final concentrations from $\mathrm{CaCl}_{2} \cdot 2 \mathrm{H}_{2} \mathrm{O}, \mathrm{CoSO}_{4} \cdot 7 \mathrm{H}_{2} \mathrm{O}, \mathrm{CuCl}_{2} \cdot 2 \mathrm{H}_{2} \mathrm{O}, \mathrm{FeCl}_{3}, \mathrm{MgCl}_{2} \cdot 6 \mathrm{H}_{2} \mathrm{O}, \mathrm{MnCl}_{2} \cdot 4 \mathrm{H}_{2} \mathrm{O}, \mathrm{RbCl}$, $\mathrm{ZnCl}_{2}, \mathrm{KCl}, \mathrm{NaCl}$ and $\mathrm{Li}$-acetate $* 2 \mathrm{H}_{2} \mathrm{O}$ salt solutions, respectively), isopropanol, ethanol, methanol, acetone, acetonitrile, DMF and DMSO (1\%, 10\% and 30\% each), Triton X-100, Tween 80 and SDS 5 (1\% and 5\% each) as well as DTT and EDTA (1, 5 and $10 \mathrm{mM}$ each).

\section{Results and Discussion}

\subsection{Homology-Based Sequence Data Mining for Lipase/Esterase Enzyme Candidates}

The established metagenomic sequence databases [13] [14] were screened for lipase enzyme candidates using 1) BLAST searches with Pfam profiles for lipases and esterases and 2) screening by a local ORF database classified by EC-number. Using Pfam profiles against the Well I and Well II metagenomics databases, 72 and 55 candidates, respectively, were identified and in total 24 candidates were found associated with E.C. number 3.1.1.3 after matching ORFs against BRENDA exemplar sequences and requiring $>60 \%$ sequence identity and $>80 \%$ coverage (Supplementary Table S1). The list of candidates from sequence mining using the Pfam strategy contained candidates with very low sequence identity to Pfam motif (annotated lipases/esterases/hydrolases). In total only 19 candidates had sequence identity higher than 30\% (37.5\% as highest). increasing the probability of false positive predictions. However, the top five candidates (37.5\% - 35.4\% id) were used in a BLASTx search, and were indeed matching esterases, hydrolases and lipolytic proteins with fairly high sequence identity ( $>80 \%)$ for most, but with some exceptions having sequence identity as low as $40 \%-50 \%$. As examples, two gene candidates from sequence mining had sequence id of $78 \%$ against alpha/beta hydrolase fold (Campylobacterales bacterium GD) and 62\% against biotin biosynthesis protein (Pelobacter carbinolicus DSM 2380), respectively (in addition verified using latest version of Pfam, resulting in abhydrolase 6, alpha/beta hydrolase family (e-value 2e-19), and abhydrolase 1, alpha/beta hydrolase fold (e-value 7e-25), respectively). These candidates 
were synthesized as codon optimized versions (GenScript) and produced in E. coli, however showing non-conclusive data in activity analysis and only moderate thermostability (data not shown). These results illustrate a key challenge of sequence mining to reliably identify candidates with the predicted enzyme activity. In the light of the obtained results, these candidates were not analyzed further. Therefore, with the purpose of finding esterase enzymes with high novelty and functionality, focus was turned to functional screening of the constructed metagenome libraries.

\subsection{Functional Screening for Lipases and Esterases}

Functional screening for long-and short-chain esterases encoded in the 11,520 arrayed fosmid clones resulted in 13 positive hits from the initial screen. For identification of the genes of interest within the respective fosmids, fosmid DNA was isolated and subjected to a combination of end-sequencing and primer walking, supplemented by 454 pyrosequencing of pooled fosmid clones. For the end-sequencing and primer walking approach, technical difficulties appeared, and sequencing results could not be correlated with fosmid size determinations by gel electrophoresis (data not shown). After thorough evaluation of the fosmid library construction procedure, it was concluded that the encountered problems likely were associated with the amplification of the metagenomic DNA. Due to the low amount of DNA that could be isolated from the oil reservoir samples, target DNA was amplified using WGA based on Multiple Strand Displacement Amplification (MDA) [25] prior to fosmid cloning. MDA has been reported earlier to result in chimeric sequences [26], and for long insert cloning (such as fosmids of around 35 kilobases in size), repetitive and chimeric DNA fragments can potentially be expected. The obtained sequencing results suggest frequent occurrence of chimeric repeats with multiple primer binding sites within the cloned inserts during end-sequencing/primer walking, hampering elucidation of the complete sequence information contained in the cloned DNA. Nevertheless, some genes potentially associated with the detected esterase phenotype could still be identified. One of these genes was found to encode a previously described lipase of Archaeoglobus fulgidus [27] which was not chosen for further analysis due to lack of novelty, as well as two other candidate genes (FS01 and FS02, with annotations as hypothetical proteins). These could be associated with strong esterase and lipase phenotypes and were therefore chosen for sub-cloning, expression from pET16b in E. coli and then subjected to further characterization. Respective crude cell extracts were produced and analyzed by esterase activity assays. Sub-cloned candidate FS01 did not show any esterase activity, whereas the FS02 clone, despite of low enzyme production levels, clearly exhibited such an activity (Figure S2). FS02 was in addition found to be highly thermostable, as incubation at $85^{\circ} \mathrm{C}$ for 30 minutes led only to a small decrease in activity compared to the not heat treated control (Figure S2).

\subsection{Analysis of the FS02 Gene}

The nucleotide sequence of the FS02 gene was used in BLASTx searches against the NCBI protein database, resulting in hits against hypothetical proteins or hydrolases of the alpha/beta superfamily (Table S2). The closest match was against a hypothetical protein encoded in the Archaeoglobus fulgidus genome [27], showing 99\% sequence identity ( 1 amino acid mismatch) by 100\% coverage. Further close homologues were a hypothetical protein from Ferroglobus placidus (60\% identity, 97\% coverage), a putative hydrolase of the alpha/beta superfamily from Archaeoglobus sulfaticallidus (55\% identity, 96\% coverage) and a hypothetical protein from Archaeoglobus veneficus SNP6 (52\% identity and 99\% coverage). For further evaluation of novelty, the FS02 amino acid sequence was combined with known lipase/esterase sequences of several Archaea and Bacteria (Table S3) in a multiple sequence alignment (Figure S3) in order to build a phylogenetic tree (Figure 1). This tree confirms the initial picture that the FS02 enzyme is closely related to predicted proteins from Archaea, but similar proteins are also found in Bacteria. Based on the functional confirmation of FS02 as an esterase, it is now possible to assign putative esterase function to these hypothetical proteins, demonstrating the strength of functional screening of metagenomes in elucidating function of the high number of genes of yet unknown function.

\subsection{Production of FS02 Enzyme and Enzyme Characterization}

Due to the apparently low production levels of FS02 enzyme in E. coli, the FS02 gene was synthesized in an $E$. coli codon usage optimized version (GenScript), cloned in the T7 expression vector pET16b and expressed in $E$. coli. Enzyme production based on the new gene version was found to be significantly higher compared to the 


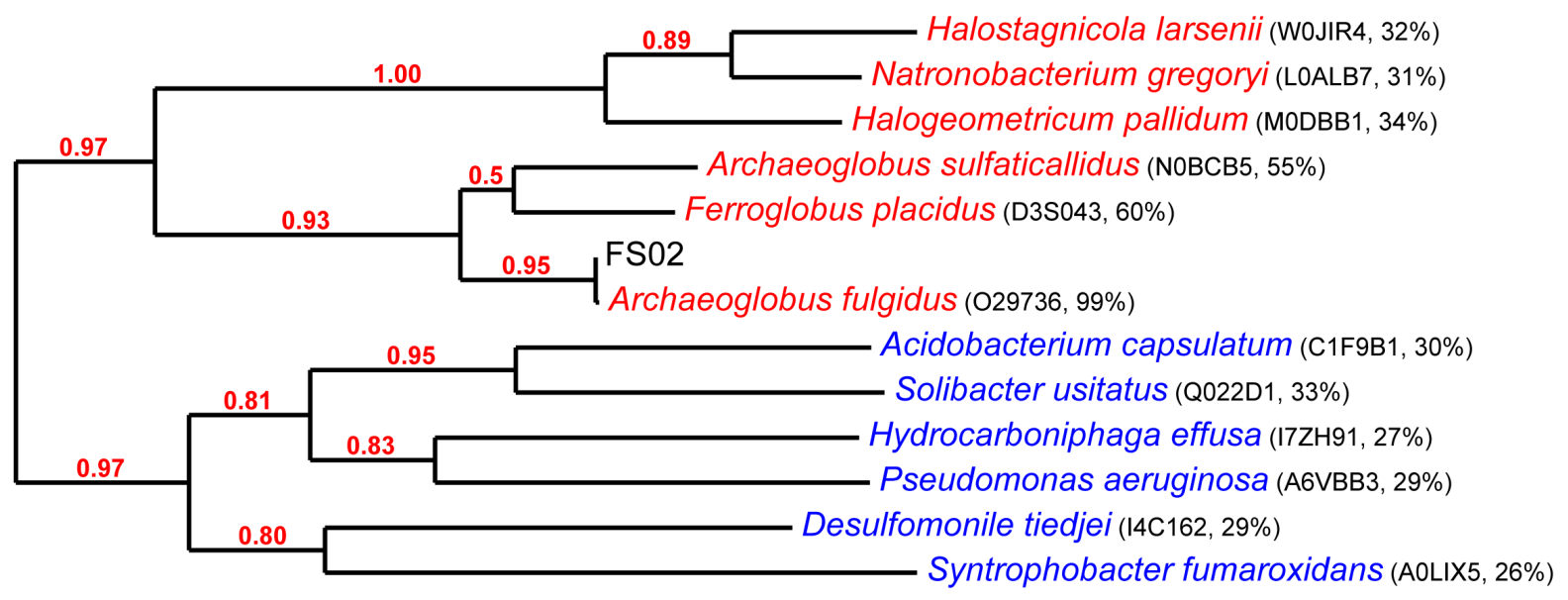

0.5

Figure 1. Phylogenetic analysis of the amino acid sequence of lipase FS02 with a selection of similar alpha/beta hydrolases (Table S2). Protein inputs are annotated as hypothetical proteins or alpha/beta hydrolases, and their respective UniProt IDs are indicated. The tree shows a clear separation into sequences from Archaea (red) and Bacteria (blue). Numbers show branch support by the approximate likelihood ratio test (aLRT).

native gene sequence (data not shown). FS02 thermostability (Figure S4) and activity were verified, and a larger batch of enzyme was produced to allow multiple analysis of the enzyme from the same batch ( 3 - $4 \mathrm{~g}$ wet cell mass/fermentor).

Batch-produced FS02 was successfully tested for heat stability by incubation at $65^{\circ} \mathrm{C}$ for 30 minutes, thus leading to an FS02 enriched crude extract for subsequent studies. The enzyme’s temperature stability was analyzed in detail by incubation at different temperatures for various periods of time, demonstrating that FS02 is thermostable up to $90^{\circ} \mathrm{C}$ for at least 1 hour without any notable decrease in activity, whereas a $100^{\circ} \mathrm{C}$ incubation resulted in rapid inactivation of the enzyme (Figure 2(a)). Longer incubation at $90^{\circ} \mathrm{C}$ resulted in lowered residual activity, however, high enzyme activity could still be detected after incubations at up to $80^{\circ} \mathrm{C}$ for as long as 5 hours (Figure 2(a)), indicating that FS02 is a highly thermostable enzyme. Tm values were determined by Thermal Shift, resulting in values of Boltzman Tm (TmB; Figure 2(b)) that were consistent with observed residual enzyme activities at high temperature. When comparing Tm values determined under different $\mathrm{pH}$ conditions, it could be concluded that the chosen $\mathrm{pH}$ range did not affect heat stability at notable levels (Figure 2(b)). In attempts to analyze the $\mathrm{pH}$ optimum of FS02, it was found that enzyme activity was high at pH 11, however, assay background was high as well at this $\mathrm{pH}$ (data not shown), and therefore $\mathrm{pH} 9$ was chosen as standard $\mathrm{pH}$ in all subsequent additional enzyme characterizations. The substrate spectrum analysis of FS02 revealed a higher enzymatic activity on short-chain substrates compared to long-chain esters (Figure 3). Enzyme activity was highest using p-nitrophenyl acetate as substrate.

Despite relatively high standard deviations in replicate measurements (Figure 4) it was found that enzyme activity on this substrate was little affected by a number of different additives, such as $\mathrm{Ca}^{2+}, \mathrm{Cu}^{2+}, \mathrm{Na}^{+}, \mathrm{Li}^{+}, \mathrm{Co}^{2+}$, $\mathrm{Fe}^{3+}$ and $\mathrm{Mg}^{2+}$ ions, as well as by addition of 5 to $10 \mathrm{mM}$ DTT (Figure 4). Ions like $\mathrm{Mn}^{2+}, \mathrm{Rb}^{2+}, \mathrm{Zn}^{2+}$ and $\mathrm{K}^{+}$ however, led to a notable increase in activity up to 5-fold. Stimulation and inhibitory effects of different metal ions on esterase activity have been observed before [28], including an increased activity in the presence of $\mathrm{Zn}^{2+}$ and a decreased activity in the presence of e.g. $\mathrm{Ca}^{2+}, \mathrm{Mn}^{2+}$ and $\mathrm{Na}^{+}$. Addition of low concentrations of detergent (1\% Triton X-100 or SDS) was found to increase activity, whereas a higher concentration of the same compounds (5\%) resulted in loss of activity, which is consistent with observations with other esterases (e.g. [29]). Presence of solvents such as ethanol, methanol, DMF, acetonitrile, acetone and isopropanol apparently led to significant increases in activity (Figure 4). Lipase activity in the presence of different solvents has been analyzed in several previous studies, mainly showing no or negative effects; e.g. unaffected activity with methanol, ethanol and acetone, and a decreased lipase activity in the presence of isopropanol [30], or reduced lipase activity in the presence of isopropanol, methanol, acetone, acetonitrile and/or ethanol [27] [29]. On the other hand, 
(a)

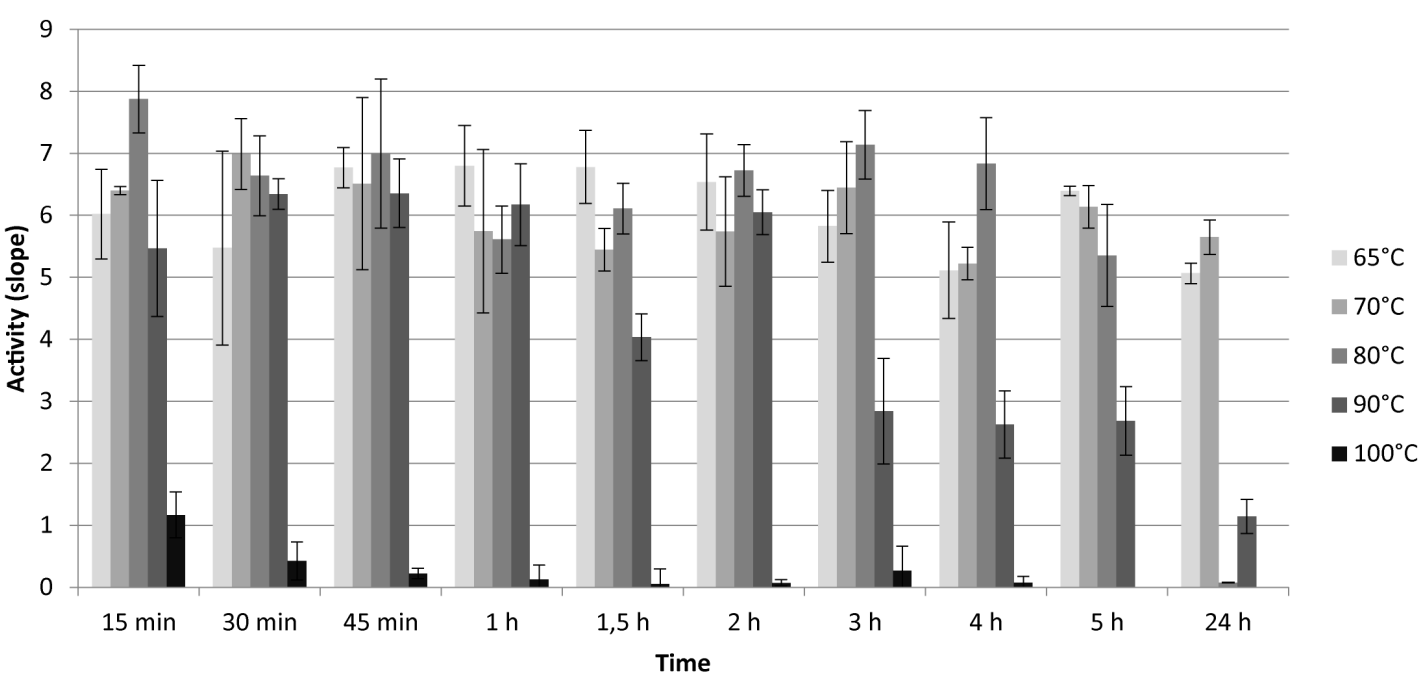

(b)

\section{Melting temperature FSO2}

\begin{tabular}{|l|l|l|}
\hline $\mathrm{pH}$ & Tm B & Stdev \\
\hline 8 & 95.90 & \pm 0.268 \\
\hline 9 & 96.14 & \pm 0.323 \\
\hline 11 & 96.01 & \pm 0.488 \\
\hline
\end{tabular}

Figure 2. Temperature stability of FS02. a) Enzyme activity assay $\left(37^{\circ} \mathrm{C}\right)$ after heat series incubation of crude cell extracts (CCE) containing FS02. Incubation at given temperatures was performed ranging from 15 min to overnight, and applying three replica measurements each. From each replicate measurement, a respective background value (using extract of cells not harboring the FS02 encoding plasmid) was subtracted (background values not exceeding 7\% of the experiment data), the resulting initial slope values of all three parallels determined and the average and standard deviation values plotted, giving the relative activity in units presented in the graph. b) Thermal shift assay of FS02 enzyme to determine melting temperatures $(\mathrm{TmB})$ at $\mathrm{pH} 8,9$ and 11 from the protein melting curve when in different $\mathrm{pH}$ buffers. Experiments were performed twice, including four replicas each. Averages and standard deviations were calculated collectively from all eight data points.

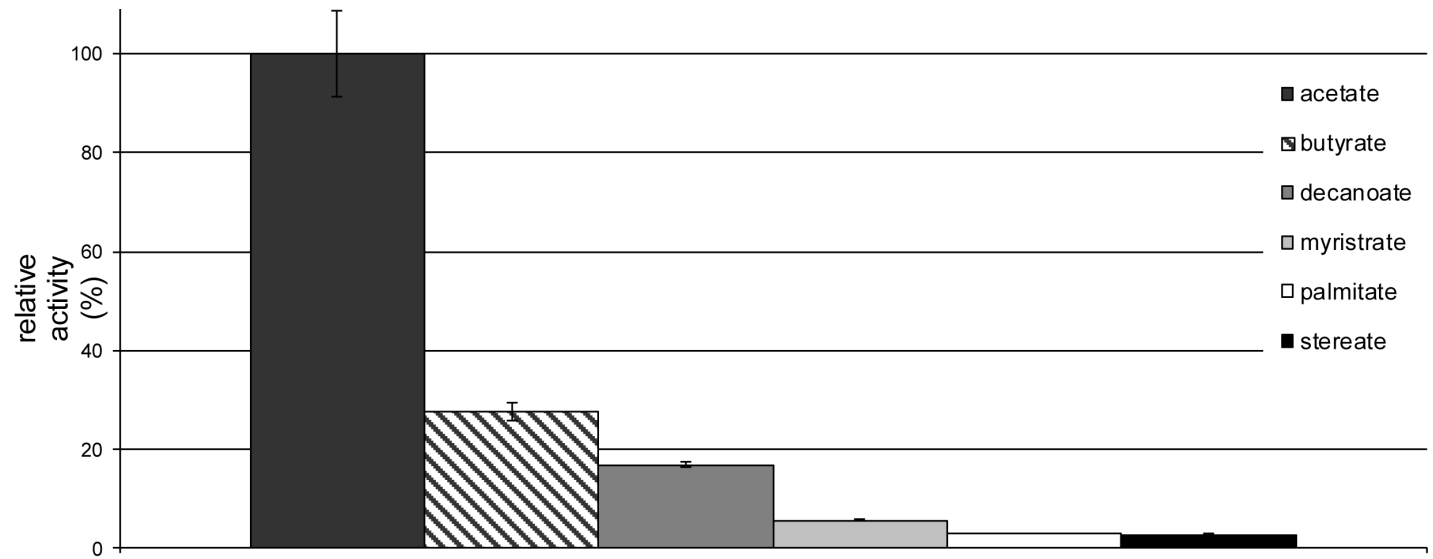

Figure 3. Determination of the substrate spectrum of FS02. Activity assays were performed for different ester substrates ranging from C2-C16. Four replica measurements were performed. Background values (based on extracts of cells not harboring the FS02 encoding plasmid) were subtracted from each measurement (background values not exceeding 16\% of the experiment data). Resulting initial slope values were determined and their average and standard deviation values plotted. The average activity value on acetate was set to $100 \%$. 


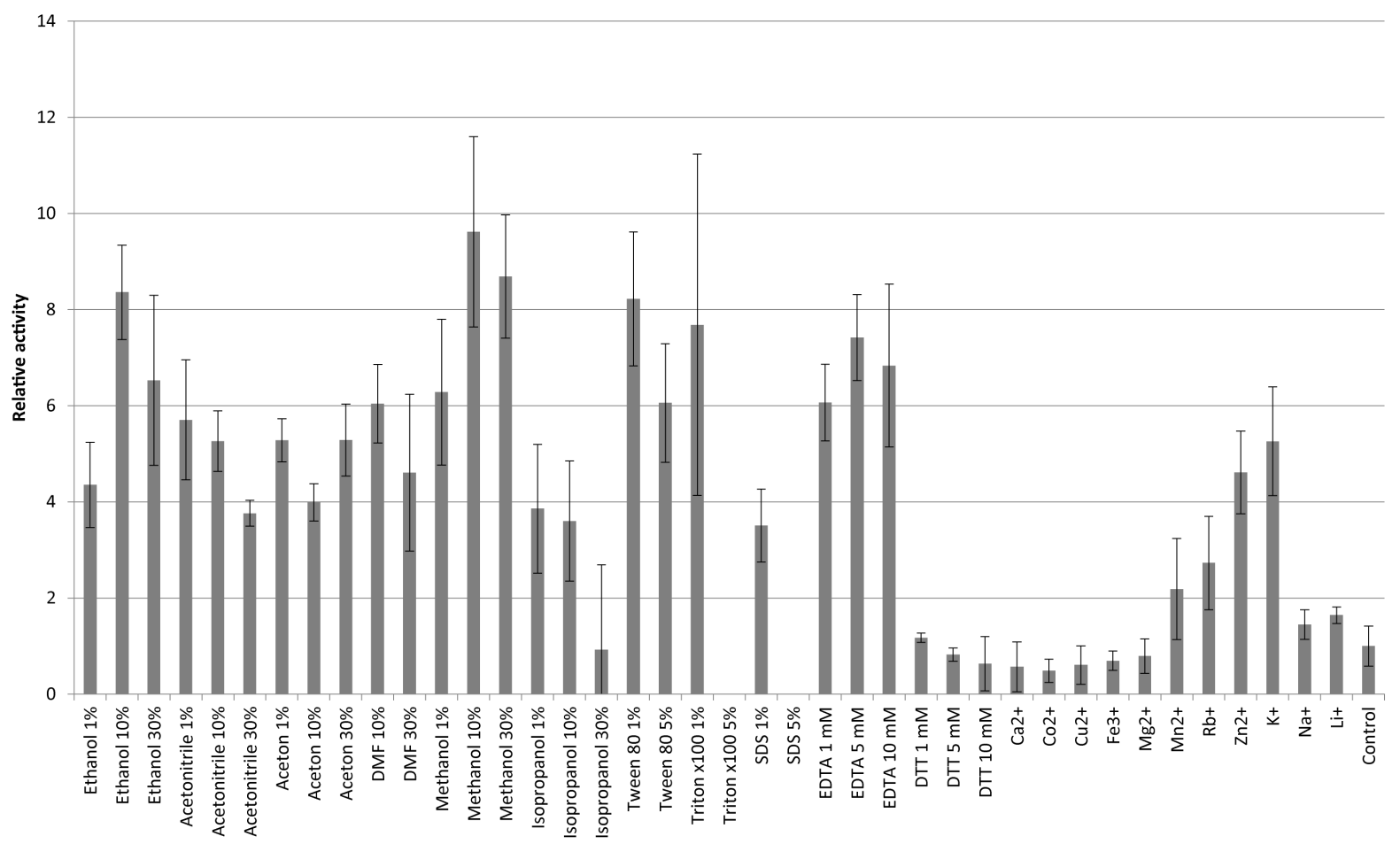

Figure 4. Lipase activity of FS02 in the presence of different additives. All experiments were performed in four replicates and are presented as mean value and standard deviations of measurements with average background (same conditions but without cell extracts) subtracted. For conditions ethanol $1 \%$ - 30\%, acetonitril $10 \%$ - 30\%, acetone 10\% - 30\%, DMF 30\%, methanol 30\%, isopropanol 10\%, Tween80 1\%, Triton X-100 1\%, EDTA $5 \mathrm{mM}, \mathrm{Ca}^{2+}, \mathrm{Co}^{2+}, \mathrm{Cu}^{2+}, \mathrm{Fe}^{3+}, \mathrm{Rb}^{+}$and $\mathrm{Li}^{+}$, each one of the four parallels was excluded as obvious outliers.

similar to the observed activity increase of FS02 in the current work, enzymatic activity of an alkaline lipase was shown to be increased in the presence of e.g. methanol [31], and high solvent tolerance of a Pseudomonas lipase has been shown [30]. Hence enzyme activity increase in the presence of solvents observed for FS02 is not unique; however, despite of some uncertainties concerning the absolute activity levels from high standard deviations in the analyses, the increases in activity observed for enzymes in previous studies are rarely as high as observed for FS02, rendering the newly discovered enzyme with distinct features compared to other similar enzymes.

\section{Conclusions}

Esterases are used in several industrial processes [1] [32], and many of these enzymes are well characterized and applied in different processes [33] [34]. However, the discovery of novel esterases with beneficial properties, e.g. high thermo-and solvent-stability, might still serve current and potential new uses in e.g. the food, polymer, pharmaceutical and fine chemical industries [32] [34]. Metagenome-based bioprospecting is a powerful tool for biodiscovery of novel enzymes for various applications, and metagenomic libraries from (poly) extreme environments might be a particularly valuable source of enzymes with unique features. Several lipase/esterase enzyme candidates were identified from the oil reservoir-originating metagenomes, both using homology-based sequence mining and functional screening. The latter helps assigning function to the vast pool of hypothetical proteins encoded and annotated in genomes and metagenomes.

One lipase/esterase candidate from functional screening, denoted FS02, was found to be active, highly thermostable, as well as showed high activity in the presence of various compounds, generating noteworthy results (Figure 4) on the enzyme's tolerance to e.g. solvents, potentially relevant for some industrial applications. Solvent tolerance is often observed for lipases (e.g. [31]), but the large stimulation of enzyme activity appears rare. However, dependent on a potentially envisioned industrial application, a more profound investigation of these 
properties will be necessary.

The discovery of an active and thermostable esterase in a metagenomic library originating from a deep subsurface oil reservoir illustrates the powerful approach of functional metagenomics in search for novel enzymes with desired properties from poly-extreme environments. It also demonstrates the potential for biodiscovery from such environments as deep subsurface oil reservoirs. The finding of the described thermostable esterase represents only the top of the ice berg of what potentially can be found by harvesting and screening metagenomes from this special ecological niche.

\section{Acknowledgements}

This work is supported by the Research Council of Norway (grant numbers 187317/S30, and 208541/O10), Statoil ASA and SINTEF.

\section{References}

[1] Whitman, W.B., Coleman, D.C. and Wiebe, W.J. (1998) Prokaryotes: The Unseen Majority. Proceedings of the National Academy of Sciences of the United States of America, 95, 6578-6583. http://dx.doi.org/10.1073/pnas.95.12.6578

[2] Wentzel, A., et al. (2013) Deep Sub-Surface Oil Reservoirs as Poly-Extreme Habitats for Microbial Life. A Current Review. In: Polyextremophiles, Volume 27 of the series Cellular Origin, Life in Extreme Habitats and Astrobiology, Springer, 439-466. http://dx.doi.org/10.1007/978-94-007-6488-0 19

[3] Lewin, A., Wentzel, A. and Valla, S. (2013) Metagenomics of Microbial Life in Extreme Temperature Environments. Current Opinion in Biotechnology, 24, 516-525. http://dx.doi.org/10.1016/j.copbio.2012.10.012

[4] Magot, M., Ollivier, B. and Patel, B.K. (2000) Microbiology of Petroleum Reservoirs. Antonie Van Leeuwenhoek, 77, 103-116. http://dx.doi.org/10.1023/A:1002434330514

[5] Orphan, V.J., et al. (2000) Culture-Dependent and Culture-Independent Characterization of Microbial Assemblages Associated with High-Temperature Petroleum Reservoirs. Applied and Environmental Microbiology, 66, 700-711. http://dx.doi.org/10.1128/AEM.66.2.700-711.2000

[6] Ramesha, B., et al. (2010) Biodiversity and Chemodiversity: Future Perspectives in Bioprospecting. Current Drug Targets, 12, 1515-1530.

[7] Lee, M.H. and Lee, S.-W. (2013) Bioprospecting Potential of the Soil Metagenome: Novel Enzymes and Bioactivities. Genomics \& Informatics, 11, 114-120. http://dx.doi.org/10.5808/GI.2013.11.3.114

[8] Koskinen, P., et al. (2008) Bioprospecting Thermophilic Microorganisms from Icelandic Hot Springs for Hydrogen and Ethanol Production. Energy \& Fuels, 22, 134-140. http://dx.doi.org/10.1021/ef700275w

[9] Novakova, J. and Farkasovsky, M. (2013) Bioprospecting Microbial Metagenome for Natural Products. Biologia, 68, 1079-1086. http://dx.doi.org/10.2478/s11756-013-0246-7

[10] Vester, J., Glaring, M. and Stougaard, P. (2015) Improved Cultivation and Metagenomics as New Tools for Bioprospecting in Cold Environments. Extremophiles, 19, 17-29. http://dx.doi.org/10.1007/s00792-014-0704-3

[11] Xu, Q., et al. (2007) Cellulases for Biomass Conversion. In: Polaina, J. and MacCabe, A.P., Eds., Industrial Enzymes, Springer, Valencia, 65-82. http://dx.doi.org/10.1007/1-4020-5377-0_3

[12] Acharya, S. and Chaudhary, A. (2012) Bioprospecting Thermophiles for Cellulase Production: A Review. Brazilian Journal of Microbiology, 43, 844-856. http://dx.doi.org/10.1590/S1517-83822012000300001

[13] Kotlar, H.K., et al. (2011) High Coverage Sequencing of DNA from Microorganisms Living in an Oil Reservoir 2.5 Kilometres Subsurface. Environmental Microbiology Reports, 3, 674-681. http://dx.doi.org/10.1111/j.1758-2229.2011.00279.x

[14] Lewin, A., et al. (2014) The Microbial Communities in Two Apparently Physically Separated Deep Subsurface Oil Reservoirs Show Extensive DNA Sequence Similarities. Environmental Microbiology, 16, 545-558.

[15] Aakvik, T., et al. (2009) A Plasmid RK2-Based Broad-Host-Range Cloning Vector Useful for Transfer of Metagenomic Libraries to a Variety of Bacterial Species. FEMS Microbiology Letters, 296, 149-158. http://dx.doi.org/10.1111/j.1574-6968.2009.01639.x

[16] Finn, R.D., et al. (2014) Pfam: The Protein Families Database. Nucleic Acids Research, 42, D222-D230. http://dx.doi.org/10.1093/nar/gkt1223

[17] Altschul, S.F., et al. (1997) Gapped BLAST and PSI-BLAST: A New Generation of Protein Database Search Programs. Nucleic Acids Research, 25, 3389-3402. http://dx.doi.org/10.1093/nar/25.17.3389

[18] Chang, A., et al. (2015) BRENDA in 2015: Exciting Developments in Its 25th Year of Existence. Nucleic Acids Re- 
search, 43, D439-D446. http://dx.doi.org/10.1093/nar/gku1068

[19] Dereeper, A., et al. (2008) Phylogeny.fr: Robust Phylogenetic Analysis for the Non-Specialist. Nucleic Acids Research, 36, W465-W469.

[20] Notredame, C., Higgins, D.G. and Heringa, J. (2000) T-Coffee: A Novel Method for Fast and Accurate Multiple Sequence Alignment. Journal of Molecular Biology, 302, 205-217. http://dx.doi.org/10.1006/jmbi.2000.4042

[21] Guindon, S., et al. (2010) New Algorithms and Methods to Estimate Maximum-Likelihood Phylogenies: Assessing the Performance of PhyML 3.0. Systematic Biology, 59, 307-321. http://dx.doi.org/10.1093/sysbio/syq010

[22] Chevenet, F., Brun, C., Bañuls, A.-L., Jacq, B. and Christen, R. (2006) TreeDyn: Towards Dynamic Graphics and Annotations for Analyses of Trees. BMC Bioinformatics, 7, 439. http://dx.doi.org/10.1186/1471-2105-7-439

[23] Anisimova, M. and Gascuel, O. (2006) Approximate Likelihood-Ratio Test for Branches: A Fast, Accurate, and Powerful Alternative. Systematic Biology, 55, 539-552. http://dx.doi.org/10.1080/10635150600755453

[24] Waterhouse, A.M., Procter, J.B., Martin, D.M.A., Clamp, M. and Barton, G.J. (2009) Jalview Version 2-A Multiple Sequence Alignment Editor and Analysis Workbench. Bioinformatics, 25, 1189-1191. http://dx.doi.org/10.1093/bioinformatics/btp033

[25] Rodrigue, S., et al. (2009) Whole Genome Amplification and De novo Assembly of Single Bacterial Cells. PLoS ONE, 4, e6864. http://dx.doi.org/10.1371/journal.pone.0006864

[26] Lasken, R.S. and Stockwell, T.B. (2007) Mechanism of Chimera Formation during the Multiple Displacement Amplification Reaction. BMC Biotechnology, 7, 19. http://dx.doi.org/10.1186/1472-6750-7-19

[27] Klenk, H.P., et al. (1997) The Complete Genome Sequence of the Hyperthermophilic, Sulphate-Reducing Archaeon Archaeoglobus fulgidus. Nature, 390, 364-370. http://dx.doi.org/10.1038/37052

[28] Ugur, A., et al. (2014) New Lipase for Biodiesel Production: Partial Purification and Characterization of LipSB 25-4. ISRN Biochemistry, 2014, Article ID: 289749.

[29] Tian, J.W., Lei, Z.C., Qiu, P., Wang, L. and Tian, Y.Q. (2014) Purification and Characterization of a Cold-Adapted Lipase from Oceanobacillus Strain PT-11. PLoS ONE, 9, e101343. http://dx.doi.org/10.1371/journal.pone.0101343

[30] Borkar, P.S., Bodade, R.G., Rao, S.R. and Khobragade, C.N. (2009) Purification and Characterization of Extracellular Lipase from a New Strain: Pseudomonas aeruginosa SRT 9. Brazilian Journal of Microbiology, 40, 358-366. http://dx.doi.org/10.1590/S1517-83822009000200028

[31] Bisht, D., Yadav, S.K. and Darmwal, N.S. (2013) An Oxidant and Organic Solvent Tolerant Alkaline Lipase by P. aeruginosa Mutant: Downstream Processing and Biochemical Characterization. Brazilian Journal of Microbiology, 44, 1305-1314. http://dx.doi.org/10.1590/S1517-83822013000400040

[32] Hasan, F., Shah, A.A. and Hameed, A. (2006) Industrial applications of Microbial Lipases. Enzyme and Microbial Technology, 39, 235-251. http://dx.doi.org/10.1016/j.enzmictec.2005.10.016

[33] Balan, A., Ibrahim, D., Abdul, R.R. and Ahmad, R.F.A. (2012) Purification and Characterization of a Thermostable Lipase from Geobacillus thermodenitrificans IBRL-nra. Enzyme Research, 2012, Article ID: 987523.

[34] Zamost, B.L., Nielsen, H.K. and Starnes, R.L. (1991) Thermostable Enzymes for Industrial Applications. Journal of Industrial Microbiology, 8, 71-81. http://dx.doi.org/10.1007/BF01578757 


\section{Appendix}

Table S1. Candidates found by sequence mining for lipases and esterases using BLAST searches against a database of Pfam profiles and a collection of exemplar sequences from BRENDA classified by EC number. The most significant hit for each contig is shown, listing Pfam or BRENDA annotation, as well as \% identity, \% coverage and e-value. For Pfam hits the \% identity is relative to the consensus sequence.

\begin{tabular}{|c|c|c|c|c|c|}
\hline Search/candidate & Candidate contig/read ID & Pfam ID/Annotation & Identity (\%) & Coverage (\%) & e-value \\
\hline Pfam1 & contig10634_532_4 & pfam00561-Abhydrolase_1 & 23.45 & 62.67 & $5.00 \mathrm{E}-12$ \\
\hline Pfam2 & contig03006_2979_63 & pfam12695-Abhydrolase_5 & 19.62 & 100 & $4.00 \mathrm{E}-18$ \\
\hline Pfam3 & contig03006_2979_63 & pfam12695-Abhydrolase_5 & 25.51 & 57.24 & $4.00 \mathrm{E}-11$ \\
\hline Pfam4 & contig06306_3078_37 & pfam12697-Abhydrolase_6 & 24.39 & 69.64 & $1.00 \mathrm{E}-05$ \\
\hline Pfam5 & contig03391_8603_101 & pfam13472-Lipase_GDSL_2 & 30.64 & 97.69 & $3.00 \mathrm{E}-30$ \\
\hline Pfam6 & contig04922_8688_114 & pfam12695-Abhydrolase_5 & 27.37 & 59.31 & $5.00 \mathrm{E}-08$ \\
\hline Pfam7 & contig05190_528_3 & pfam12695-Abhydrolase_5 & 28.75 & 52.41 & $3.00 \mathrm{E}-14$ \\
\hline Pfam8 & contig07066_7149_180 & pfam12697-Abhydrolase_6 & 33.06 & 54.02 & $1.00 \mathrm{E}-20$ \\
\hline Pfam9 & contig04904_2432_80 & pfam13472-Lipase_GDSL_2 & 16.98 & 52.60 & $8.00 \mathrm{E}-09$ \\
\hline Pfam10 & FYXZCPA02FPU0B_473_1 & pfam07859-Abhydrolase_3 & 21.56 & 74.88 & $3.00 \mathrm{E}-07$ \\
\hline Pfam11 & contig06801_3003_27 & pfam13472-Lipase_GDSL_2 & 32.95 & 100 & $3.00 \mathrm{E}-28$ \\
\hline Pfam12 & contig03009_1909_60 & pfam06821-Ser_hydrolase & 37.50 & 97.08 & $1.00 \mathrm{E}-46$ \\
\hline Pfam13 & contig08344_800_5 & pfam12697-Abhydrolase_6 & 18.59 & 78.13 & $2.00 \mathrm{E}-06$ \\
\hline Pfam14 & contig03736_4913_82 & pfam12695-Abhydrolase_5 & 23.40 & 63.4483 & $1.00 \mathrm{E}-05$ \\
\hline Pfam15 & contig06405_970_8 & pfam12697-Abhydrolase_6 & 30.00 & 99.1071 & $1.00 \mathrm{E}-50$ \\
\hline Pfam16 & FYXZCPA02G140B_424_1 & pfam12695-Abhydrolase_5 & 33.33 & 62.7586 & $6.00 \mathrm{E}-18$ \\
\hline Pfam16 & contig01573_4582_113 & pfam12695-Abhydrolase_5 & 25.29 & 100 & $1.00 \mathrm{E}-12$ \\
\hline Pfam17 & contig05511_3393_28 & pfam12697-Abhydrolase_6 & 19.26 & 96.4286 & $1.00 \mathrm{E}-13$ \\
\hline Pfam18 & FYXZCPA02IP2FT_387_1 & pfam12697-Abhydrolase_6 & 22.83 & 55.3571 & $6.00 \mathrm{E}-10$ \\
\hline Pfam19 & contig02150_5033_123 & pfam12697-Abhydrolase_6 & 19.40 & 88.8393 & $7.00 \mathrm{E}-07$ \\
\hline Pfam2 & contig03063_7553_90 & pfam12697-Abhydrolase_6 & 19.83 & 96.875 & $2.00 \mathrm{E}-19$ \\
\hline Pfam21 & contig08668_499_3 & pfam12697-Abhydrolase_6 & 36.09 & 56.6964 & $2.00 \mathrm{E}-17$ \\
\hline Pfam22 & FYXZCPA01BCVY3_478_1 & pfam12695-Abhydrolase_5 & 30.59 & 53.7931 & $4.00 \mathrm{E}-12$ \\
\hline Pfam23 & contig01280_2950_36 & pfam12697-Abhydrolase_6 & 21.30 & 95.9821 & $9.00 \mathrm{E}-23$ \\
\hline Pfam24 & contig07165_797_5 & pfam12695-Abhydrolase_5 & 16.50 & 100 & $1.00 \mathrm{E}-10$ \\
\hline Pfam25 & contig00489_2553_26 & pfam00561-Abhydrolase_1 & 22.34 & 97.3333 & $1.00 \mathrm{E}-20$ \\
\hline Pfam26 & contig06642_507_3 & pfam12697-Abhydrolase_6 & 24.18 & 61.6071 & $4.00 \mathrm{E}-16$ \\
\hline Pfam27 & contig07477_1639_15 & pfam00561-Abhydrolase_1 & 18.12 & 62.2222 & $4.00 \mathrm{E}-12$ \\
\hline Pfam28 & contig02638_1148_7 & pfam12695-Abhydrolase_5 & 27.91 & 50.3448 & $3.00 \mathrm{E}-08$ \\
\hline Pfam29 & contig09772_490_3 & pfam12695-Abhydrolase_5 & 20.75 & 79.3103 & $4.00 \mathrm{E}-13$ \\
\hline Pfam30 & contig01826_5617_105 & pfam12697-Abhydrolase_6 & 19.40 & 95.5357 & $1.00 \mathrm{E}-08$ \\
\hline Pfam31 & contig11358_484_4 & pfam12697-Abhydrolase_6 & 35.40 & 50.4464 & $6.00 \mathrm{E}-33$ \\
\hline Pfam32 & contig02573_1545_14 & pfam12697-Abhydrolase_6 & 21.43 & 66.5179 & $2.00 \mathrm{E}-08$ \\
\hline Pfam33 & FYXZCPA02INS3R_479_1 & pfam13472-Lipase_GDSL_2 & 22.66 & 69.9422 & $4.00 \mathrm{E}-09$ \\
\hline Pfam34 & FYXZCPA02I0GHD_502_1 & pfam12697-Abhydrolase_6 & 20.83 & 50.8929 & $5.00 \mathrm{E}-13$ \\
\hline Pfam35 & FYXZCPA01DINQ9_368_1 & pfam12695-Abhydrolase_5 & 27.27 & 56.5517 & $4.00 \mathrm{E}-09$ \\
\hline Pfam36 & FYXZCPA01CXWGZ_504_1 & pfam13472-Lipase_GDSL_2 & 21.35 & 50.8671 & $1.00 \mathrm{E}-12$ \\
\hline Pfam37 & contig02497_4406_116 & pfam00561-Abhydrolase_1 & 18.70 & 89.7778 & $2.00 \mathrm{E}-10$ \\
\hline Pfam38 & contig05216_3751_38 & pfam12697-Abhydrolase_6 & 25.58 & 92.8571 & $3.00 \mathrm{E}-22$ \\
\hline Pfam39 & contig02933_3670_42 & pfam12697-Abhydrolase_6 & 19.70 & 80.3571 & $6.00 \mathrm{E}-13$ \\
\hline Pfam 40 & contig01893_2307_67 & pfam13472-Lipase_GDSL_2 & 36.72 & 98.2659 & $4.00 \mathrm{E}-28$ \\
\hline Pfam41 & contig10277_498_3 & pfam12697-Abhydrolase_6 & 22.01 & 66.0714 & $1.00 \mathrm{E}-20$ \\
\hline Pfam42 & FYXZCPA02IIP42_477_1 & pfam12697-Abhydrolase_6 & 36.59 & 54.4643 & $1.00 \mathrm{E}-29$ \\
\hline
\end{tabular}




\section{Continued}

\begin{tabular}{|c|c|c|c|c|c|}
\hline Pfam43 & contig00476_8726_271 & pfam12697-Abhydrolase_6 & 24.03 & 98.6607 & $5.00 \mathrm{E}-36$ \\
\hline Pfam44 & FYXZCPA01E5UXP_460_1 & pfam12695-Abhydrolase_5 & 31.00 & 63.4483 & $3.00 \mathrm{E}-15$ \\
\hline Pfam45 & contig04216_513_5 & pfam12695-Abhydrolase_5 & 30.00 & 64.1379 & $8.00 \mathrm{E}-20$ \\
\hline Pfam46 & contig02413_18858_411 & pfam12695-Abhydrolase_5 & 25.70 & 100 & $2.00 \mathrm{E}-22$ \\
\hline Pfam47 & contig00197_534_3 & pfam12695-Abhydrolase_5 & 29.00 & 64.1379 & $2.00 \mathrm{E}-19$ \\
\hline Pfam48 & FYXZCPA02GZ6XY_538_1 & pfam12695-Abhydrolase_5 & 21.29 & 77.2414 & $3.00 \mathrm{E}-09$ \\
\hline Pfam49 & FYXZCPA02GN27Q_460_1 & pfam12695-Abhydrolase_5 & 20.83 & 52.4138 & $1.00 \mathrm{E}-06$ \\
\hline Pfam50 & FYXZCPA01DX4R7_474_1 & pfam12697-Abhydrolase_6 & 27.27 & 54.0179 & $3.00 \mathrm{E}-20$ \\
\hline Pfam51 & contig00250_28097_740 & pfam12695-Abhydrolase_5 & 27.03 & 74.4828 & $1.00 \mathrm{E}-15$ \\
\hline Pfam52 & FYXZCPA01A44W5_490_1 & pfam12695-Abhydrolase_5 & 24.49 & 81.3793 & $8.00 \mathrm{E}-10$ \\
\hline Pfam53 & contig04095_6514_173 & pfam12697-Abhydrolase_6 & 18.71 & 67.4107 & $2.00 \mathrm{E}-06$ \\
\hline Pfam54 & contig00394_1735_8 & pfam12695-Abhydrolase_5 & 20.60 & 100 & $3.00 \mathrm{E}-15$ \\
\hline Pfam55 & contig07114_639_5 & pfam12695-Abhydrolase_5 & 24.77 & 65.5172 & $1.00 \mathrm{E}-17$ \\
\hline Pfam56 & contig04783_1443_31 & pfam12697-Abhydrolase_6 & 24.00 & 51.3393 & $1.00 \mathrm{E}-11$ \\
\hline Pfam57 & contig00882_9723_289 & pfam12697-Abhydrolase_6 & 22.07 & 93.3036 & $2.00 \mathrm{E}-16$ \\
\hline Pfam58 & contig01290_10856_428 & pfam00561-Abhydrolase_1 & 16.30 & 97.3333 & $1.00 \mathrm{E}-11$ \\
\hline Pfam59 & FYXZCPA02HSGF6_484_1 & pfam12697-Abhydrolase_6 & 33.06 & 53.5714 & $6.00 \mathrm{E}-20$ \\
\hline Pfam60 & FYXZCPA02JVPXC_526_1 & pfam00561-Abhydrolase_1 & 16.55 & 62.6667 & $4.00 \mathrm{E}-07$ \\
\hline Pfam61 & contig01615_9318_182 & pfam13472-Lipase_GDSL_2 & 34.66 & 100 & $3.00 \mathrm{E}-28$ \\
\hline Pfam62 & FYXZCPA02H13EN_510_1 & pfam12695-Abhydrolase_5 & 30.00 & 60.6897 & $6.00 \mathrm{E}-15$ \\
\hline Pfam63 & contig08515_1275_11 & pfam12697-Abhydrolase_6 & 20.32 & 80.8036 & $2.00 \mathrm{E}-18$ \\
\hline Pfam64 & contig06241_7320_88 & pfam12697-Abhydrolase_6 & 25.31 & 91.9643 & $5.00 \mathrm{E}-26$ \\
\hline Pfam65 & contig01479_20270_446 & pfam12697-Abhydrolase_6 & 30.33 & 100 & $1.00 \mathrm{E}-33$ \\
\hline Pfam66 & contig05933_1877_36 & pfam00756-Esterase & 32.33 & 100 & $1.00 \mathrm{E}-58$ \\
\hline Pfam67 & contig06201_5298_75 & pfam12695-Abhydrolase_5 & 24.00 & 64.1379 & $3.00 \mathrm{E}-10$ \\
\hline Pfam68 & FYXZCPA01DJ12Y_449_1 & pfam12695-Abhydrolase_5 & 25.47 & 64.1379 & $4.00 \mathrm{E}-17$ \\
\hline Pfam69 & contig01611_15601_375 & pfam12695-Abhydrolase_5 & 26.03 & 97.2414 & $2.00 \mathrm{E}-12$ \\
\hline Pfam70 & contig00834_8473_222 & pfam00561-Abhydrolase_1 & 22.32 & 94.2222 & $9.00 \mathrm{E}-16$ \\
\hline Pfam71 & contig01303_2032_11 & pfam12695-Abhydrolase_5 & 25.77 & 52.4138 & $2.00 \mathrm{E}-07$ \\
\hline Pfam72 & GJ054VR02ISR5J_494_1 & pfam13472-Lipase_GDSL_2 & 15.79 & 57.2254 & $7.00 \mathrm{E}-08$ \\
\hline Pfam73 & GJ054VR02HA4RF_492_1 & pfam12697-Abhydrolase_6 & 20.96 & 65.625 & $5.00 \mathrm{E}-13$ \\
\hline Pfam74 & contig10048_381_3 & pfam12697-Abhydrolase_6 & 16.41 & 51.3393 & $5.00 \mathrm{E}-06$ \\
\hline Pfam75 & contig07636_309_2 & pfam12695-Abhydrolase_5 & 25.00 & 54.4828 & $1.00 \mathrm{E}-06$ \\
\hline Pfam76 & GJ054VR01C67B5_457_1 & pfam13472-Lipase_GDSL_2 & 26.47 & 64.1618 & $1.00 \mathrm{E}-15$ \\
\hline Pfam77 & contig02952_2692_17 & pfam12697-Abhydrolase_6 & 24.64 & 85.2679 & $9.00 \mathrm{E}-27$ \\
\hline Pfam78 & contig00620_19347_416 & pfam12697-Abhydrolase_6 & 26.22 & 97.3214 & $6.00 \mathrm{E}-29$ \\
\hline Pfam79 & contig00889_16596_343 & pfam12697-Abhydrolase_6 & 25.77 & 100 & $4.00 \mathrm{E}-27$ \\
\hline Pfam80 & contig03816_967_7 & pfam12695-Abhydrolase_5 & 24.48 & 84.1379 & $5.00 \mathrm{E}-09$ \\
\hline Pfam81 & contig08847_841_6 & pfam12695-Abhydrolase_5 & 24.83 & 97.2414 & $2.00 \mathrm{E}-10$ \\
\hline Pfam82 & contig05729_1202_11 & pfam02230-Abhydrolase_2 & 27.10 & 93.4272 & $1.00 \mathrm{E}-28$ \\
\hline Pfam83 & contig10760_22051_6260 & pfam12697-Abhydrolase_6 & 27.39 & 97.7679 & $1.00 \mathrm{E}-29$ \\
\hline Pfam84 & GJ054VR02FQQYK_497_1 & pfam12695-Abhydrolase_5 & 21.56 & 99.3103 & $1.00 \mathrm{E}-14$ \\
\hline Pfam85 & contig00012_70893_20885 & pfam12695-Abhydrolase_5 & 16.50 & 100 & $2.00 \mathrm{E}-07$ \\
\hline Pfam86 & contig02372_1061_6 & pfam12697-Abhydrolase_6 & 26.88 & 66.0714 & $1.00 \mathrm{E}-05$ \\
\hline Pfam87 & contig00035_25497_6840 & pfam12695-Abhydrolase_5 & 20.50 & 99.3103 & $1.00 \mathrm{E}-08$ \\
\hline Pfam88 & GJ054VR02IK5IL_506_1 & pfam12695-Abhydrolase_5 & 31.68 & 66.2069 & $1.00 \mathrm{E}-19$ \\
\hline Pfam89 & contig03737_2033_16 & pfam12695-Abhydrolase_5 & 27.97 & 66.2069 & $5.00 \mathrm{E}-11$ \\
\hline Pfam90 & contig01505_1164_6 & pfam12697-Abhydrolase_6 & 23.33 & 87.9464 & $7.00 \mathrm{E}-19$ \\
\hline
\end{tabular}




\begin{tabular}{|c|c|c|c|c|c|}
\hline \multicolumn{6}{|l|}{ Continued } \\
\hline Pfam91 & contig00049_11245_240 & pfam12697-Abhydrolase_6 & 21.43 & 66.5179 & $3.00 \mathrm{E}-07$ \\
\hline Pfam92 & GJ054VR01EWNW0_530_1 & pfam12695-Abhydrolase_5 & 27.93 & 60.6897 & $2.00 \mathrm{E}-08$ \\
\hline Pfam93 & GJ054VR01BPBL5_460_1 & pfam12697-Abhydrolase_6 & 29.51 & 50.4464 & $1.00 \mathrm{E}-24$ \\
\hline Pfam94 & contig00454_19280_412 & pfam12697-Abhydrolase_6 & 30.17 & 100 & $1.00 \mathrm{E}-42$ \\
\hline Pfam95 & contig00119_19232_365 & pfam12697-Abhydrolase_6 & 19.26 & 96.4286 & $1.00 \mathrm{E}-12$ \\
\hline Pfam96 & contig00119_19232_365 & pfam12695-Abhydrolase_5 & 24.00 & 64.1379 & $1.00 \mathrm{E}-08$ \\
\hline Pfam97 & GJ054VR01CNOSD_447_1 & pfam12695-Abhydrolase_5 & 25.25 & 57.931 & $4.00 \mathrm{E}-14$ \\
\hline Pfam98 & contig00960_13684_281 & pfam12697-Abhydrolase_6 & 27.43 & 100 & $3.00 \mathrm{E}-39$ \\
\hline Pfam99 & contig07622_1530_12 & pfam12697-Abhydrolase_6 & 25.00 & 82.5893 & $6.00 \mathrm{E}-23$ \\
\hline Pfam100 & GJ054VR02H7I8R_531_1 & pfam00561-Abhydrolase_1 & 24.85 & 74.6667 & $2.00 \mathrm{E}-17$ \\
\hline Pfam101 & GJ054VR02G60MH_452_1 & pfam12697-Abhydrolase_6 & 23.08 & 58.0357 & $5.00 \mathrm{E}-17$ \\
\hline Pfam102 & GJ054VR02JWL8C_458_1 & pfam02230-Abhydrolase_2 & 20.98 & 58.216 & $8.00 \mathrm{E}-08$ \\
\hline Pfam103 & contig07870_496_3 & pfam12697-Abhydrolase_6 & 15.20 & 72.3214 & $2.00 \mathrm{E}-06$ \\
\hline Pfam104 & contig10986_45864_11909 & pfam12697-Abhydrolase_6 & 31.22 & 95.5357 & $2.00 \mathrm{E}-27$ \\
\hline Pfam105 & GJ054VR01BULKR_485_1 & pfam13472-Lipase_GDSL_2 & 28.87 & 82.0809 & $2.00 \mathrm{E}-27$ \\
\hline Pfam106 & contig01919_852_7 & pfam13472-Lipase_GDSL_2 & 30.99 & 94.7977 & $5.00 \mathrm{E}-25$ \\
\hline Pfam107 & contig03267_4254_30 & pfam12695-Abhydrolase_5 & 25.00 & 80 & $2.00 \mathrm{E}-09$ \\
\hline Pfam108 & contig00064_9159_317 & pfam00756-Esterase & 32.33 & 100 & $4.00 \mathrm{E}-54$ \\
\hline Pfam109 & contig08275_501_3 & pfam12695-Abhydrolase_5 & 22.12 & 60.6897 & $3.00 \mathrm{E}-06$ \\
\hline Pfam111 & GJ054VR01C7J7L_531_1 & pfam13472-Lipase_GDSL_2 & 32.41 & 57.8035 & $3.00 \mathrm{E}-17$ \\
\hline Pfam112 & contig03549_307_2 & pfam12695-Abhydrolase_5 & 23.91 & 57.931 & $3.00 \mathrm{E}-16$ \\
\hline Pfam113 & GJ054VR01DFKXI_458_1 & pfam12697-Abhydrolase_6 & 29.55 & 58.4821 & $3.00 \mathrm{E}-25$ \\
\hline Pfam114 & GJ054VR02HLP9Q_442_1 & pfam12697-Abhydrolase_6 & 19.05 & 60.7143 & $4.00 \mathrm{E}-10$ \\
\hline Pfam115 & contig00103_70784_19920 & pfam12697-Abhydrolase_6 & 24.02 & 96.875 & $3.00 \mathrm{E}-19$ \\
\hline Pfam116 & contig01310_928_5 & pfam12695-Abhydrolase_5 & 30.28 & 70.3448 & $5.00 \mathrm{E}-23$ \\
\hline Pfam117 & GJ054VR01B2IB1_498_1 & pfam12697-Abhydrolase_6 & 17.05 & 57.1429 & $4.00 \mathrm{E}-11$ \\
\hline Pfam118 & contig00490_53254_1018 & pfam12697-Abhydrolase_6 & 26.75 & 98.2143 & $6.00 \mathrm{E}-23$ \\
\hline Pfam119 & GJ054VR01D1B3V_512_1 & pfam12695-Abhydrolase_5 & 27.36 & 63.4483 & $7.00 \mathrm{E}-10$ \\
\hline Pfam120 & GJ054VR01C6IR9_411_1 & pfam12695-Abhydrolase_5 & 19.05 & 68.9655 & $2.00 \mathrm{E}-16$ \\
\hline Pfam121 & contig00981_111696_2437 & pfam00561-Abhydrolase_1 & 22.34 & 97.3333 & $2.00 \mathrm{E}-18$ \\
\hline Pfam122 & contig00363_90062_1905 & pfam12697-Abhydrolase_6 & 19.70 & 80.3571 & $2.00 \mathrm{E}-11$ \\
\hline Pfam123 & contig07913_1207_7 & pfam12697-Abhydrolase_6 & 18.80 & 99.5536 & $4.00 \mathrm{E}-07$ \\
\hline Pfam124 & contig08413_774_5 & pfam12697-Abhydrolase_6 & 23.91 & 97.3214 & $2.00 \mathrm{E}-40$ \\
\hline Pfam125 & contig00941_2929_50 & pfam12695-Abhydrolase_5 & 28.24 & 56.5517 & $7.00 \mathrm{E}-10$ \\
\hline Pfam126 & contig00109_61254_1373 & pfam13472-Lipase_GDSL_2 & 22.99 & 100 & $1.00 \mathrm{E}-24$ \\
\hline Pfam127 & contig00271_130367_2942 & pfam12695-Abhydrolase_5 & 27.37 & 59.3103 & $8.00 \mathrm{E}-07$ \\
\hline E.C. no. 1 & contig01459_13828_351 & triacylglycerol lipase & 76.75 & 77.82 & $1.00 \mathrm{E}-90$ \\
\hline E.C. no. 2 & FYXZCPA01D1H7X_445_1 & protein-glutamate methylesterase & 53.15 & 88.80 & $5.00 \mathrm{E}-29$ \\
\hline E.C. no. 3 & FYXZCPA01EWMQU_502_1 & protein-glutamate methylesterase & 52.63 & 55.07 & $9.00 \mathrm{E}-06$ \\
\hline E.C. no. 4 & FYXZCPA01ATIY8_536_1 & triacylglycerol lipase & 50.96 & 61.33 & $2.00 \mathrm{E}-38$ \\
\hline E.C. no. 5 & contig01695_17539_381 & protein-glutamate methylesterase & 77.60 & 55.01 & $3.00 \mathrm{E}-84$ \\
\hline E.C. no. 6 & contig07322_3581_40 & triacylglycerol lipase & 60.40 & 99.60 & $2.00 \mathrm{E}-70$ \\
\hline E.C. no. 7 & FYXZCPA02J31IF_470_1 & protein-glutamate methylesterase & 94.55 & 69.62 & $3.00 \mathrm{E}-55$ \\
\hline E.C. no. 8 & contig07990_2621_29 & protein-glutamate methylesterase & 74.50 & 99.43 & $2.00 \mathrm{E}-157$ \\
\hline
\end{tabular}




\section{Continued}

\begin{tabular}{|c|c|c|c|c|c|}
\hline E.C. no. 9 & contig10134_349_3 & protein-glutamate methylesterase & 51.76 & 60.43 & $5.00 \mathrm{E}-17$ \\
\hline E.C. no. 10 & contig01574_9423_255 & protein-glutamate methylesterase & 54.29 & 50.72 & $4.00 \mathrm{E}-04$ \\
\hline E.C. no. 11 & contig04439_2235_47 & protein-glutamate methylesterase & 54.96 & 52.49 & $2.00 \mathrm{E}-72$ \\
\hline E.C. no. 12 & contig07769_983_5 & protein-glutamate methylesterase & 54.31 & 92.80 & $2.00 \mathrm{E}-31$ \\
\hline E.C. no. 13 & contig05129_1344_6 & protein-glutamate methylesterase & 59.58 & 97.90 & $3.00 \mathrm{E}-121$ \\
\hline E.C. no. 14 & contig01573_4582_113 & carboxymethylenebutenolidase & 54.38 & 85.38 & $6.00 \mathrm{E}-52$ \\
\hline E.C. no. 15 & contig09355_501_4 & protein-glutamate methylesterase & 62.50 & 84.55 & $1.00 \mathrm{E}-34$ \\
\hline E.C. no. 16 & FYXZCPA01C4V38_432_1 & triacylglycerol lipase & 51.41 & 56.71 & $9.00 \mathrm{E}-19$ \\
\hline E.C. no. 17 & contig05158_2403_20 & protein-glutamate methylesterase & 50.85 & 50.64 & $8.00 \mathrm{E}-25$ \\
\hline E.C. no. 18 & contig04980_2741_49 & protein-glutamate methylesterase & 53.38 & 97.79 & $2.00 \mathrm{E}-35$ \\
\hline E.C. no. 19 & contig00779_27300_655 & protein-glutamate methylesterase & 77.68 & 99.44 & $2.00 \mathrm{E}-160$ \\
\hline E.C. no. 20 & FYXZCPA02JFV78_481_1 & protein-glutamate methylesterase & 50.00 & 68.80 & $2.00 \mathrm{E}-20$ \\
\hline E.C. no. 21 & contig01548_1890_12 & protein-glutamate methylesterase & 54.29 & 50.72 & $2.00 \mathrm{E}-05$ \\
\hline E.C. no. 22 & FYXZCPA02HPIN0_465_1 & 6-phosphogluconolactonase & 95.48 & 53.63 & $3.00 \mathrm{E}-74$ \\
\hline E.C. no. 23 & contig00680_7380_200 & protein-glutamate methylesterase & 62.16 & 97.76 & $2.00 \mathrm{E}-75$ \\
\hline E.C. no. 24 & FYXZCPA01AW52H_501_1 & protein-glutamate methylesterase & 64.38 & 58.40 & $4.00 \mathrm{E}-24$ \\
\hline E.C. no. 25 & contig04738_1406_28 & protein-glutamate methylesterase & 52.21 & 83.70 & $6.00 \mathrm{E}-27$ \\
\hline E.C. no. 26 & contig01007_1067_9 & triacylglycerol lipase & 75.79 & 82.25 & $1.00 \mathrm{E}-70$ \\
\hline E.C. no. 27 & contig01899_519_4 & triacylglycerol lipase & 50.29 & 50.88 & $3.00 \mathrm{E}-48$ \\
\hline E.C. no. 28 & contig04083_1665_9 & protein-glutamate methylesterase & 50.42 & 93.60 & $8.00 \mathrm{E}-28$ \\
\hline E.C. no. 29 & contig00864_10444_246 & protein-glutamate methylesterase & 54.79 & 99.47 & $2.00 \mathrm{E}-53$ \\
\hline E.C. no. 30 & contig01748_3935_54 & triacylglycerol lipase & 65.05 & 90.88 & $5.00 \mathrm{E}-117$ \\
\hline E.C. no. 31 & contig01312_6616_156 & triacylglycerol lipase & 78.60 & 98.28 & $9.00 \mathrm{E}-86$ \\
\hline E.C. no. 32 & contig00956_967_6 & protein-glutamate methylesterase & 60.07 & 79.17 & $4.00 \mathrm{E}-93$ \\
\hline E.C. no. 33 & contig03179_1774_53 & protein-glutamate methylesterase & 50.56 & 73.55 & $3.00 \mathrm{E}-22$ \\
\hline E.C. no. 34 & contig05175_614_5 & protein-glutamate methylesterase & 51.35 & 88.80 & $2.00 \mathrm{E}-29$ \\
\hline E.C. no. 35 & contig04148_2863_53 & protein-glutamate methylesterase & 51.11 & 59.42 & $4.00 \mathrm{E}-04$ \\
\hline E.C. no. 36 & contig01109_4523_139 & protein-glutamate methylesterase & 51.33 & 98.67 & $2.00 \mathrm{E}-41$ \\
\hline E.C. no. 37 & FYXZCPA02IIP42_477_1 & 3-oxoadipate enol-lactonase & 75.84 & 55.19 & $2.00 \mathrm{E}-60$ \\
\hline E.C. no. 38 & FYXZCPA01CK4RL_454_1 & protein-glutamate methylesterase & 52.70 & 58.73 & $6.00 \mathrm{E}-16$ \\
\hline E.C. no. 39 & contig06284_1669_16 & protein-glutamate methylesterase & 51.26 & 95.20 & $9.00 \mathrm{E}-30$ \\
\hline E.C. no. 40 & FYXZCPA02GN27Q_460_1 & acetylcholinesterase & 56.49 & 57.09 & $5.00 \mathrm{E}-41$ \\
\hline E.C. no. 41 & contig01142_9836_320 & protein-glutamate methylesterase & 78.51 & 97.58 & $3.00 \mathrm{E}-52$ \\
\hline E.C. no. 42 & contig05497_1971_21 & protein-glutamate methylesterase & 50.00 & 92.11 & $2.00 \mathrm{E}-45$ \\
\hline E.C. no. 43 & contig00811_7133_147 & protein-glutamate methylesterase & 72.13 & 100.00 & $1.00 \mathrm{E}-141$ \\
\hline E.C. no. 44 & contig03571_4243_108 & protein-glutamate methylesterase & 51.22 & 58.91 & $2.00 \mathrm{E}-56$ \\
\hline E.C. no. 45 & contig00177_37689_2549 & protein-glutamate methylesterase & 64.58 & 99.18 & $7.00 \mathrm{E}-137$ \\
\hline E.C. no. 46 & contig01355_5503_132 & protein-glutamate methylesterase & 51.30 & 92.00 & $2.00 \mathrm{E}-26$ \\
\hline E.C. no. 47 & contig07567_976_5 & triacylglycerol lipase & 56.25 & 52.03 & $2.00 \mathrm{E}-61$ \\
\hline E.C. no. 48 & contig04073_10150_130 & 6-phosphogluconolactonase & 70.09 & 92.24 & $7.00 \mathrm{E}-73$ \\
\hline E.C. no. 49 & contig04394_3033_83 & protein-glutamate methylesterase & 60.83 & 96.77 & $3.00 \mathrm{E}-37$ \\
\hline E.C. no. 50 & contig00873_13383_308 & protein-glutamate methylesterase & 55.26 & 55.07 & $5.00 \mathrm{E}-05$ \\
\hline E.C. no. 51 & contig00238_4315_99 & protein-glutamate methylesterase & 60.21 & 82.65 & $1.00 \mathrm{E}-101$ \\
\hline E.C. no. 52 & contig01644_12678_360 & protein-glutamate methylesterase & 51.79 & 52.58 & $5.00 \mathrm{E}-23$ \\
\hline
\end{tabular}




\section{Continued}

\begin{tabular}{|c|c|c|c|c|c|}
\hline E.C. no. 53 & contig05752_1086_9 & protein-glutamate methylesterase & 54.70 & 63.59 & $5.00 \mathrm{E}-87$ \\
\hline E.C. no. 54 & contig06520_2685_59 & protein-glutamate methylesterase & 51.20 & 98.81 & $2.00 \mathrm{E}-90$ \\
\hline E.C. no. 55 & FYXZCPA01D95YE_442_1 & protein-glutamate methylesterase & 50.00 & 54.03 & $4.00 \mathrm{E}-09$ \\
\hline E.C. no. 56 & contig12591_616_6 & protein-glutamate methylesterase & 50.43 & 53.99 & $1.00 \mathrm{E}-22$ \\
\hline E.C. no. 57 & contig01479_20270_446 & protein-glutamate methylesterase & 50.82 & 93.85 & $6.00 \mathrm{E}-32$ \\
\hline E.C. no. 58 & contig04528_7408_175 & protein-glutamate methylesterase & 62.18 & 96.75 & $5.00 \mathrm{E}-41$ \\
\hline E.C. no. 59 & contig01961_1964_14 & protein-glutamate methylesterase & 62.50 & 89.82 & $6.00 \mathrm{E}-120$ \\
\hline E.C. no. 60 & contig05933_1877_36 & carboxylesterase & 72.10 & 97.18 & $6.00 \mathrm{E}-119$ \\
\hline E.C. no. 61 & FYXZCPA02JFTDD_499_1 & protein-glutamate methylesterase & 50.00 & 56.97 & $5.00 \mathrm{E}-32$ \\
\hline E.C. no. 62 & contig02175_3096_107 & protein-glutamate methylesterase & 54.46 & 99.11 & $5.00 \mathrm{E}-49$ \\
\hline E.C. no. 63 & contig05606_1287_8 & protein-glutamate methylesterase & 65.03 & 55.04 & $2.00 \mathrm{E}-58$ \\
\hline E.C. no. 64 & contig08366_295_2 & protein-glutamate methylesterase & 51.81 & 65.35 & $2.00 \mathrm{E}-18$ \\
\hline E.C. no. 65 & contig03691_2959_22 & protein-glutamate methylesterase & 58.57 & 51.85 & $8.00 \mathrm{E}-20$ \\
\hline E.C. no. 66 & contig06683_514_3 & protein-glutamate methylesterase & 50.39 & 94.85 & $8.00 \mathrm{E}-33$ \\
\hline E.C. no. 67 & GJ054VR02IO0TL_534_1 & triacylglycerol lipase & 50.39 & 59.76 & $7.00 \mathrm{E}-53$ \\
\hline E.C. no. 68 & GJ054VR01CUP6J_454_1 & protein-glutamate methylesterase & 52.94 & 75.56 & $6.00 \mathrm{E}-23$ \\
\hline E.C. no. 69 & contig00456_28478_646 & protein-glutamate methylesterase & 50.23 & 96.09 & $7.00 \mathrm{E}-49$ \\
\hline E.C. no. 70 & contig03921_533_3 & protein-glutamate methylesterase & 64.22 & 88.62 & $7.00 \mathrm{E}-38$ \\
\hline E.C. no. 71 & contig10760_22051_6260 & triacylglycerol lipase & 81.57 & 99.22 & $2.00 \mathrm{E}-115$ \\
\hline E.C. no. 72 & contig04473_1195_7 & protein-glutamate methylesterase & 50.43 & 85.19 & $4.00 \mathrm{E}-26$ \\
\hline E.C. no. 73 & GJ054VR02GCI2F_479_1 & protein-glutamate methylesterase & 50.00 & 97.60 & $1.00 \mathrm{E}-33$ \\
\hline E.C. no. 74 & GJ054VR01EFZ0J_498_1 & protein-glutamate methylesterase & 62.50 & 59.02 & $3.00 \mathrm{E}-49$ \\
\hline E.C. no. 75 & contig07065_401_2 & protein-glutamate methylesterase & 50.00 & 60.87 & $6.00 \mathrm{E}-06$ \\
\hline E.C. no. 76 & contig02240_1506_10 & protein-glutamate methylesterase & 50.00 & 55.61 & $1.00 \mathrm{E}-27$ \\
\hline E.C. no. 77 & contig05971_806_4 & protein-glutamate methylesterase & 51.69 & 73.55 & $6.00 \mathrm{E}-23$ \\
\hline E.C. no. 78 & GJ054VR02JO9KC_470_1 & protein-glutamate methylesterase & 51.28 & 95.12 & $5.00 \mathrm{E}-27$ \\
\hline E.C. no. 79 & contig04043_1277_11 & protein-glutamate methylesterase & 50.44 & 83.70 & $1.00 \mathrm{E}-27$ \\
\hline E.C. no. 80 & contig00960_13684_281 & protein-glutamate methylesterase & 65.05 & 90.88 & $5.00 \mathrm{E}-117$ \\
\hline E.C. no. 81 & GJ054VR01B5TSY_488_1 & protein-glutamate methylesterase & 78.51 & 97.58 & $2.00 \mathrm{E}-52$ \\
\hline E.C. no. 82 & GJ054VR02II30F_510_1 & protein-glutamate methylesterase & 51.96 & 81.60 & $6.00 \mathrm{E}-27$ \\
\hline E.C. no. 83 & contig00732_3200_23 & protein-glutamate methylesterase & 57.14 & 50.72 & $8.00 \mathrm{E}-04$ \\
\hline E.C. no. 84 & GJ054VR02H7I8R_531_1 & dihydrocoumarin hydrolase & 60.23 & 63.77 & $2.00 \mathrm{E}-59$ \\
\hline E.C. no. 85 & contig00987_35243_1622 & protein-glutamate methylesterase & 64.58 & 99.18 & $7.00 \mathrm{E}-137$ \\
\hline E.C. no. 86 & contig03267_4254_30 & Carboxymethylenebutenolidase & 53.18 & 67.98 & $4.00 \mathrm{E}-42$ \\
\hline E.C. no. 87 & contig00064_9159_317 & carboxylesterase & 72.10 & 97.18 & $6.00 \mathrm{E}-119$ \\
\hline E.C. no. 88 & GJ054VR02JYT6B_479_1 & protein-glutamate methylesterase & 62.03 & 63.20 & $1.00 \mathrm{E}-24$ \\
\hline E.C. no. 89 & contig00955_1565_14 & triacylglycerol lipase & 78.09 & 60.75 & $6.00 \mathrm{E}-71$ \\
\hline E.C. no. 90 & contig07351_1200_9 & protein-glutamate methylesterase & 54.29 & 50.72 & $6.00 \mathrm{E}-04$ \\
\hline E.C. no. 91 & contig05469_1382_15 & protein-glutamate methylesterase & 54.76 & 59.42 & $8.00 \mathrm{E}-05$ \\
\hline E.C. no. 92 & contig04613_1156_8 & protein-glutamate methylesterase & 55.10 & 87.50 & $5.00 \mathrm{E}-10$ \\
\hline E.C. no. 93 & contig05233_960_7 & protein-glutamate methylesterase & 51.43 & 50.72 & $2.00 \mathrm{E}-04$ \\
\hline E.C. no. 94 & contig06045_1712_10 & protein-glutamate methylesterase & 62.61 & 72.78 & $6.00 \mathrm{E}-37$ \\
\hline E.C. no. 95 & contig05435_745_4 & protein-glutamate methylesterase & 50.00 & 81.63 & $2.00 \mathrm{E}-06$ \\
\hline
\end{tabular}




\section{Continued}

\begin{tabular}{|c|c|c|c|c|c|}
\hline E.C. no. 96 & contig00154_53031_1113 & protein-glutamate methylesterase & 50.85 & 50.64 & $6.00 \mathrm{E}-25$ \\
\hline E.C. no. 97 & GJ054VR02F0FR6_436_1 & protein-glutamate methylesterase & 61.74 & 51.11 & $6.00 \mathrm{E}-28$ \\
\hline E.C. no. 98 & GJ054VR01A7XTC_544_1 & protein-glutamate methylesterase & 80.21 & 51.28 & $5.00 \mathrm{E}-78$ \\
\hline E.C. no. 99 & contig06676_1954_11 & protein-glutamate methylesterase & 54.29 & 53.60 & $1.00 \mathrm{E}-15$ \\
\hline $\begin{array}{c}\text { E.C. no. } \\
100\end{array}$ & contig01396_3317_22 & triacylglycerol lipase & 51.28 & 80.29 & $3.00 \mathrm{E}-79$ \\
\hline $\begin{array}{c}\text { E.C. no. } \\
101\end{array}$ & contig09830_293_3 & protein-glutamate methylesterase & 58.76 & 59.88 & $5.00 \mathrm{E}-29$ \\
\hline $\begin{array}{c}\text { E.C. no. } \\
102\end{array}$ & contig00023_26624_552 & 6-phosphogluconolactonase & 69.06 & 96.12 & $1.00 \mathrm{E}-76$ \\
\hline $\begin{array}{c}\text { E.C. no. } \\
103\end{array}$ & GJ054VR02GMPRP_548_1 & triacylglycerol lipase & 84.03 & 62.34 & $5.00 \mathrm{E}-58$ \\
\hline $\begin{array}{c}\text { E.C. no. } \\
104\end{array}$ & GJ054VR01EH9PQ_550_1 & protein-glutamate methylesterase & 50.00 & 67.86 & $1.00 \mathrm{E}-05$ \\
\hline $\begin{array}{c}\text { E.C. no. } \\
105\end{array}$ & GJ054VR01CJYLF_496_1 & protein-glutamate methylesterase & 50.00 & 50.38 & $3.00 \mathrm{E}-10$ \\
\hline $\begin{array}{c}\text { E.C. no. } \\
106\end{array}$ & contig00373_119927_2499 & protein-glutamate methylesterase & 74.36 & 100.00 & $2.00 \mathrm{E}-157$ \\
\hline $\begin{array}{c}\text { E.C. no. } \\
107\end{array}$ & GJ054VR01BUKCP_412_1 & triacylglycerol lipase & 59.12 & 53.52 & $2.00 \mathrm{E}-46$ \\
\hline
\end{tabular}

Table S2. Blastx search using FS02 sequence.

\begin{tabular}{lllll}
\hline Protein hit & Score & Query coverage & E-value & Ident \\
\hline Hypothetical protein AF0514 (Archaeoglobus fulgidus DSM 4304) & 377 & $100 \%$ & $2 \mathrm{e}-131$ & $99 \%$ \\
Hypothetical protein Ferp 1969 (Ferroglobus placidus DSM10642) & 227 & $97 \%$ & $3 \mathrm{e}-72$ & $60 \%$ \\
Putative hydrolase of alpha/beta superfamily (Archaeoglobus sulfaticallidus) & 214 & $96 \%$ & $4 \mathrm{e}-67$ & $55 \%$ \\
Hypothetical protein Arcve 1663 (Archaeoglobus veneficus SNP6) & 190 & $99 \%$ & $1 \mathrm{e}-57$ & $52 \%$ \\
Hydrolase of alpha/beta superfamily (Natronobacterium gregoryi SP2) & 100 & $100 \%$ & $8 \mathrm{e}-23$ & $31 \%$ \\
Hypothetical protein HacjB3 (Halalkalicoccus jeotgali) & 99.0 & $96 \%$ & $3 \mathrm{e}-22$ & $32 \%$ \\
Hypothetical protein (Haloferax larsenii) & 98.6 & $93 \%$ & $5 \mathrm{e}-22$ & $32 \%$ \\
Hypothetical protein (Haloferax elongans) & 98.2 & $93 \%$ & $5 \mathrm{e}-22$ & $32 \%$ \\
Alpha/beta hydrolase (Halostagnicola larsenii XH-48) & 97.8 & $98 \%$ & $7 \mathrm{e}-22$ & $32 \%$ \\
Hydrolase of alpha/beta superfamily-like protein (Natrialba taiwanensis) & 96.7 & $97 \%$ & $2 \mathrm{e}-21$ & $32 \%$ \\
Hydrolase of alpha/beta superfamily-like protein (Natroncoccus amylolyticus) & 97.4 & $98 \%$ & $2 \mathrm{e}-21$ & $32 \%$ \\
Alpha/beta hydrolase (Halosarcina pallida) & 94.4 & $91 \%$ & $1 \mathrm{e}-20$ & $34 \%$ \\
\hline
\end{tabular}

Table S3. Protein sequences used for phylogenetic analysis.

\begin{tabular}{|c|c|c|c|c|c|}
\hline Uniprot ID & NCBI RefSeq & Archaea/Bacteria & Species & Annotation & $\begin{array}{l}\text { Identity } \\
\text { to FS02 }\end{array}$ \\
\hline W0JIR4 & WP_049951831.1 & A & Halostagnicola larsenii & alpha/beta hydrolase & $32 \%$ \\
\hline L0ALB7 & WP_005580491.1 & A & Natronobacterium gregoryi & alpha/beta hydrolase & $31 \%$ \\
\hline M0DBB1 & WP_008384884.1 & A & Halogeometricum pallidum & alpha/beta hydrolase & $34 \%$ \\
\hline N0BCB5 & WP_015590857.1 & A & Archaeoglobus sulfaticallidus & $\begin{array}{l}\text { hydrolase of the alpha/beta } \\
\text { superfamily }\end{array}$ & $55 \%$ \\
\hline D3S043 & WP_012966445.1 & A & Ferroglobus placidus & hypothetical protein & $60 \%$ \\
\hline O29736 & WP_010878021.1 & A & Archaeoglobus fulgidus & hypothetical protein & $99 \%$ \\
\hline C1F9B1 & WP_012680666.1 & $\mathrm{B}$ & Acidobacterium capsulatum & alpha/beta hydrolase & $30 \%$ \\
\hline Q022D1 & WP_011684934.1 & B & Solibacter usitatus & hypothetical protein & $33 \%$ \\
\hline I7ZH91 & WP_007184188.1 & B & Hydrocarboniphaga effuse & hypothetical protein & $27 \%$ \\
\hline A6VBB3 & WP_003150434.1 & $\mathrm{B}$ & Pseudomonas aeruginosa & alpha/beta hydrolase & $29 \%$ \\
\hline I4C162 & WP_052315987.1 & B & Desulfomonile tiedjei & hypothetical protein & $29 \%$ \\
\hline A0LIX5 & WP_011698547.1 & $\mathrm{B}$ & Syntrophobacter fumaroxidans & alpha/beta hydrolase family protein & $26 \%$ \\
\hline
\end{tabular}




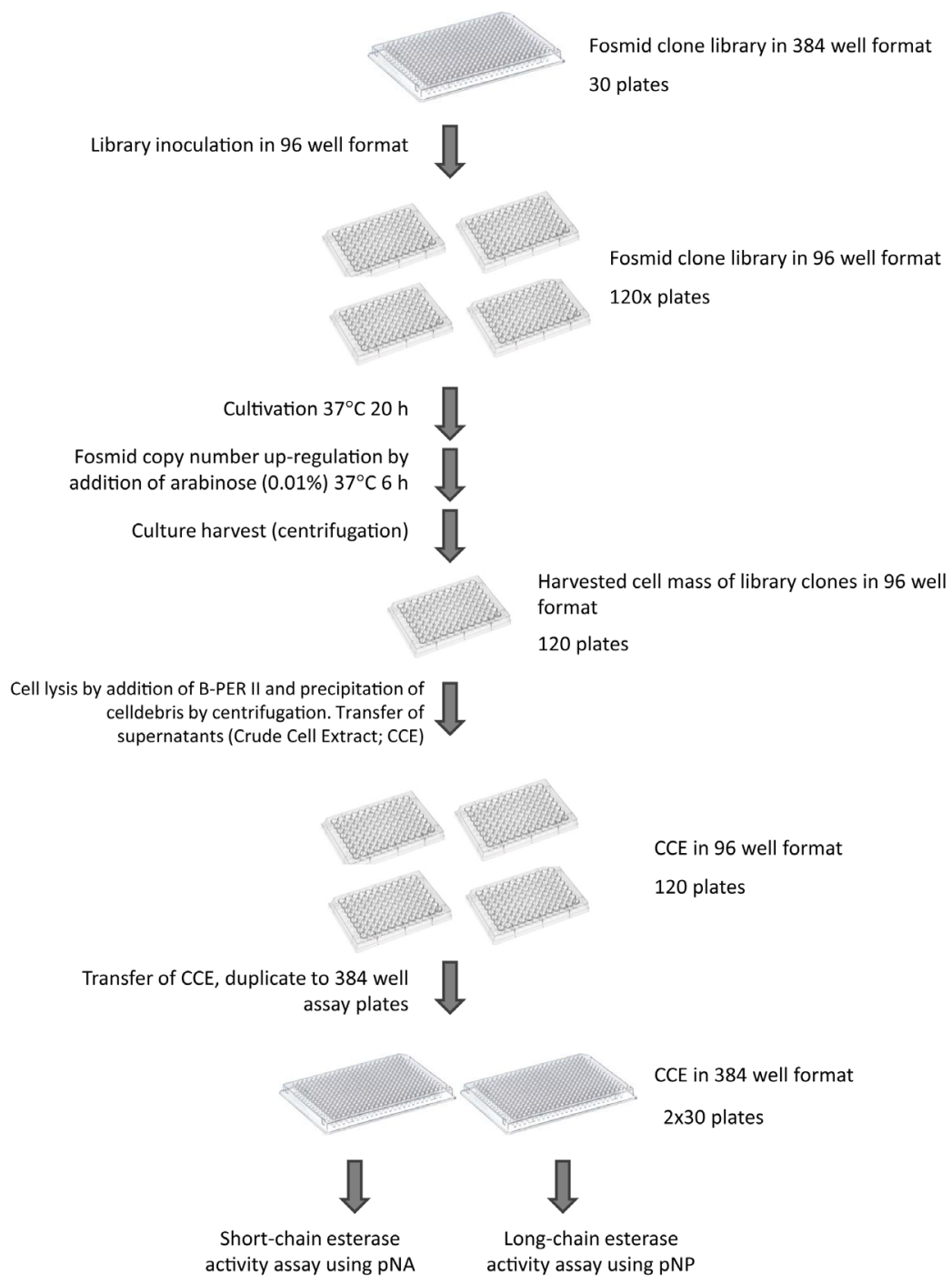

Figure S1. Schematic overview of functional screening experiment set-up. For details on experimental conditions it is referred to the Materials and Methods section.

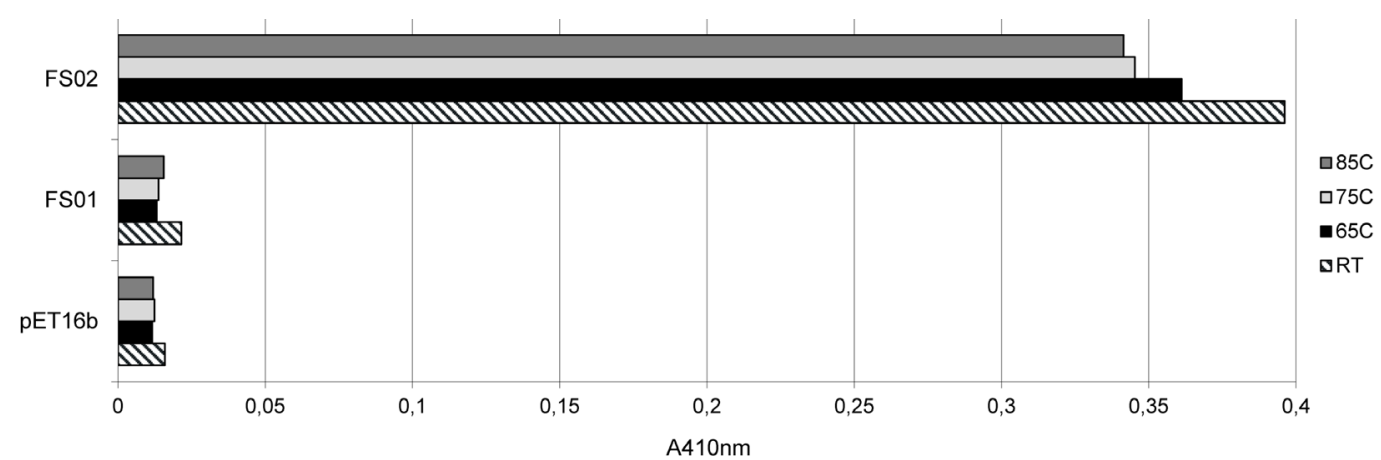

Figure S2. End-point (30 min) long-chain esterase assay (substrate; 4-Nitrophenyl palmitate) using crude cell extracts containing FS01 and FS02 from expression of the native sequence from pET16b in E. coli BL21 (DE3) RELP (codon+). Extracts were pre-incubated for 30 minutes at $20^{\circ} \mathrm{C}, 65^{\circ} \mathrm{C}, 75^{\circ} \mathrm{C}$ or $85^{\circ} \mathrm{C}$, respectively, and the remaining soluble fraction assayed. FS02 activity (measured at $37^{\circ} \mathrm{C}$ ) was found well over background (empty pET16b vector control), and remained even after incubation at $85^{\circ} \mathrm{C}$, indicating high thermostability of FS02. In contrast, FS01 did not show any measureable esterase activity. 
FS02 ||/1-187

C1F9B1 $\mathrm{B} \mid \mathrm{A} / 1-220$

Q022D1 $|\mathrm{B}| \mathrm{S} / 1-210$ I4C162 $|\mathrm{B}| \mathrm{D} / 1-217$

A0LIX5 $|\mathrm{B}| \mathrm{S} / 1-212$

I7ZH91 $|\mathrm{B}| \mathrm{H} / \mathrm{1}-22$ A6VBB3 $|\mathrm{B}| \mathrm{P} / 1-209$ 029736 | A A $/ 1-187$ D3S043 |A F/1-186 NOBCB5 $|\mathrm{A}| \mathrm{A} / 1-18$ MODBB 1 A A H $/ 1-206$ W0JIR4 $|\mathrm{A}| \mathrm{H} / 1-209$ LOALB7 |A | N/1-203

Conservatin

FS02 $\mid / 1-187$ C1F9B1 $|\mathrm{B}| \mathrm{A} / 1-220$ Q022D1|B|S/1-210 I4C162 B D/1-217 A0LIX5 $|\mathrm{B}| \mathrm{S} / 1-212$ I7ZH91 |B $\mid \mathrm{H} / 1-228$ A6VBB3 B P/1-209 029736 |A A/ $1-187$ D3S043|A F/1-186 NOBCB5 $|\mathrm{A}| \mathrm{A} / 1-181$ MODBB1 $|\mathrm{A}| \mathrm{H} / 1-206$ WOJIR4 $|\mathrm{A}| \mathrm{H} / \mathrm{1}-209$ LOALB7 |A | N/1-203

Conservatio

FS02 | / 1-187 C1F9B1 |B $\mid$ A $/ 1-220$ Q022D1 |B |S/1-210 I4C162 B $\mid \mathrm{D} / 1-217$ A0LIX5 $|\mathrm{B}| \mathrm{S} / 1-212$ I7ZH91 $|\mathrm{B}| \mathrm{H} / 1-228$ A6VBB3 $|\mathrm{B}| \mathrm{P} / 1-209$ 029736 $|\mathrm{A}| \mathrm{A} / \mathrm{1}-18$ D3S043 A $\mid \mathrm{F} / 1-186$ NOBCB5 $|A| A / 1-181$ NODBB1 $|\mathrm{A}| \mathrm{H} / 1-206$ W0JIR4 | A | H/1-209 LOALB7 |A N/1-203

Conservatin

FS02 ||/1-187 C1F9B1 | B A A $1-220$ Q022D1 B $\mid$ S/1-210 I4C162 |B | D/1-217 AOLIX5 $|\mathrm{B}| \mathrm{S} / 1-2$ T7ZH91 B $\mathrm{H} / 1-228$ A6VBB3 $|\mathrm{B}| \mathrm{P} / \mathrm{1}-209$ 029736 A A A $1-187$ D3S043 A A F / 1-186 NOBCB5 $|\mathrm{A}| \mathrm{A} / 1-18$ MODBB1 $|\mathrm{A}| \mathrm{H} / 1-206$ W0JIR4 $|\mathrm{A}| \mathrm{H} / 1-209$ LOALB7 $|\mathrm{A}| \mathrm{N} / 1-203$

Conservatin

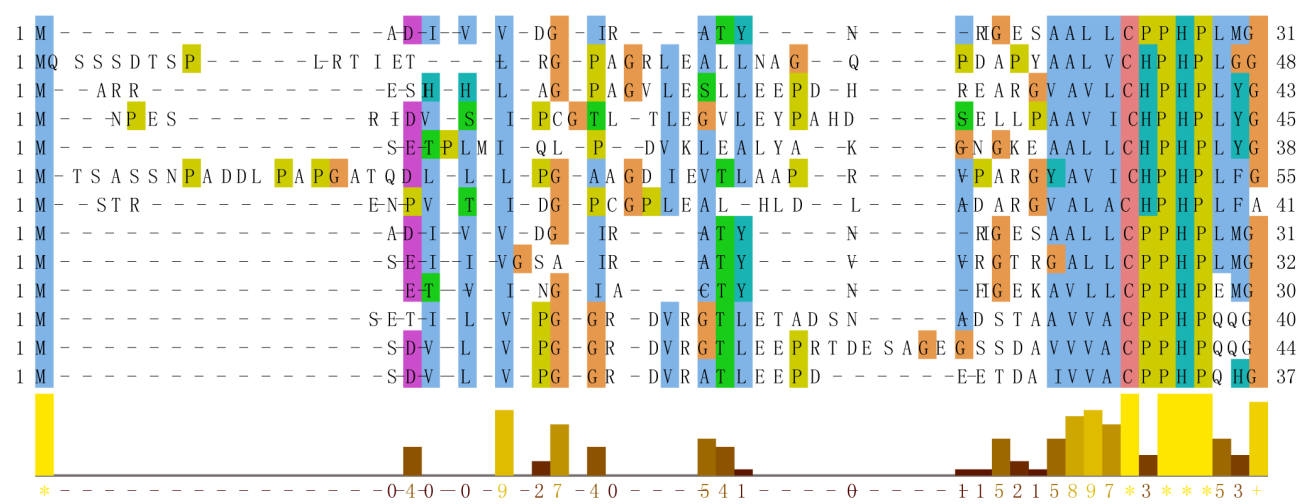

32 GSRF DVRLER IAAE LTKRNVSVLRFDY QR P - - - - FRSG I GEVEDAKKCVAYLKD- - RH - D - - K - - 85

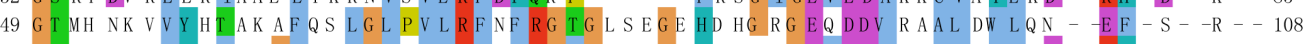
44 G IMH NK VVYRMARGLRRAGFVVLRFNFRG VG ASEGEHAHLEGE IEDARAAL AW LRD- RY - L- -EL- 104 46 GNMH NS VVRAVRTAF LEYGAVALRFNF RG TGAS WG THGEG IDE IQDVLAAL DF LQK QE RV-DSQR--109 39 GS SD NNV VQALQE TYEKSGFGTLRFNFRGVGRSEGVYGRGQSEARDVLGM AS YLRE - - QGFE - -V - - 99 56 GAMS NK VTYTLAS I ALKAGFYALRFNFRG VGKSAG THDEGVGETEDTLLMVDW LRQ - - R-MP - -AAS 117 42 G T MQ NK VVATLQR AAR DA GLATLRFNFRG VGQS AG SYAEG IGE IDDA EAAAR WL LE - - RH-P- - GL - 102 32 GS RF DV RLER IAAE LTKRNVSVLRFDY QR P - - - - FRSG IGEVEDAKKCVAYLKD - - RH - D - - K - 85 33 GSRFDVRLER IAAELHK INYSTLAFDYRTP- - - - FRGG VGE IEDARSCLLYLKE - - RH - D - - F - - 86 31 GSRFDV R IMR ISEELND AG ITTLAF DY RKP- - - - FR DG VGEVEDAIAC LRF LRE - -RF - E- -S - - 84 41 GHRG DERLVAVADE LTDRG VDCLRFDY - - - - GP WD EGRGEREDAAR AVEWVTE- - RY - D - - R - - 93 45 GSRSDQRLVAVSEALLEAGIACLRFDY - - - - GRWDEGGEREDVRNA IRWA GE - RY - D - - R - - 97 38 GSRTDG RLVAMSEALTDRS I ACLRFDY - - - - GQ WD DG YGELADVRNAVCWA DG - RY - D - - R - 90

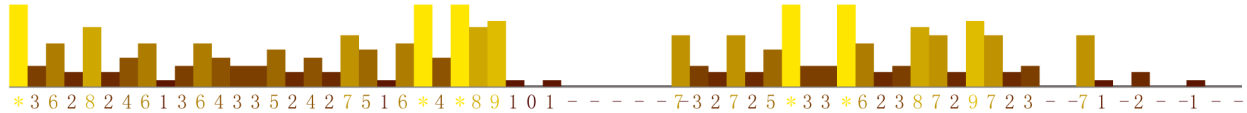

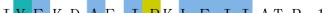

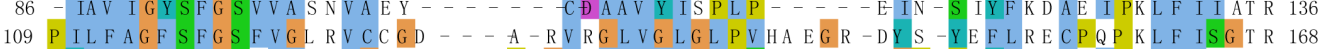
105 PYALAGFSFGSRVITRLGCAV- - P -GAVFLUA AGFPT- - R -WG P-PEHLESCRVPKIFIQSTN 160 110 - LGV AG YSFGSWVGLNAASRD- - - S-RPVSUIG ISPPL - - - E-ASD-FSFLKHEKRPKL LLVGD 164 100 - LHG AAY SYGVWV LL I AAGLG- - t-KVESLVLASPPV - - - - FLP-FDELQL PAEPSLVTLGS 154 118 PLLLAGFSFGGYVSVRAER - - - A-RPNLQISVAPPF - - GG-RFAYAERPQRPDCPWLVIHSRD 174 103 PLTLMG FSFG S V AGN LAGRLEAQDV-ALARLFM I APPV- - - E-RFA--V-SLPGRCPLTVIQPED 160 86 - IAV IRYSFGSVVASNVAEY - . - - CAAAVYISPLP - . - E IN-S IYFKDAE I PKLFIIATR 136

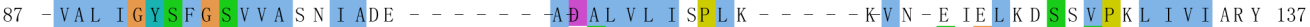

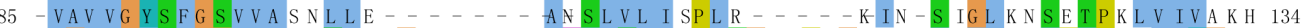
94 - AGLFGFSFGAVALLTAADG- - - A-DVEAVSALAPASGL-PDGSDA-VAAFEE IPVPVQVVYGTR 152 98 - VGVFGYSFGATLALLAPADV- - - ĐPSPDA VAVLAPTARL - ADDL DA - LEAMG SLESPLCVLYGER 157 91 -VGLFGYSFGATLAL IATDDL - - E-TVDA VSALAPTAHL -GADLDA - LEALESLSVPIQVLYGER 149

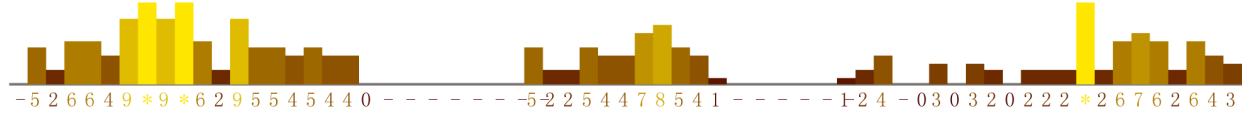

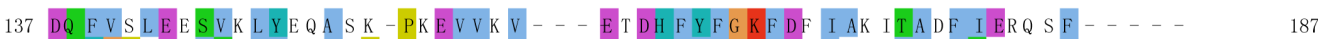

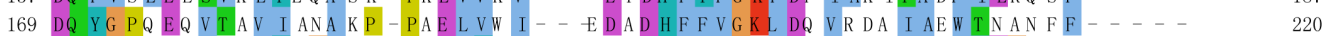
161 DQ YGPRME LEEMY QGFAA - PKE IHW I - EASDHFFAGALDA LEEQVFRAAEGY . . . . 165 DFVCSVSSFRKLVAAIPE - PKKG IVL - - KG HD HF HFGQEDDLVREMKSFLRGLPHD - 155 DQ F C AV DS LQS WL DG AS A - P D - LVHVE I LPV CD HF YWEREEALSEFVASFLKDHVAR TA T- 212

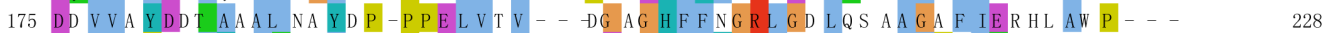
161 DDVVTPSAVYAWS ESLAR - PHE LLRV_. AESGHFFHGKL I ELKDLLLPRLQD _......

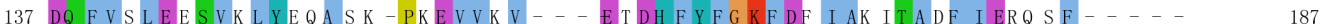

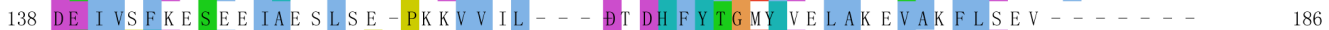

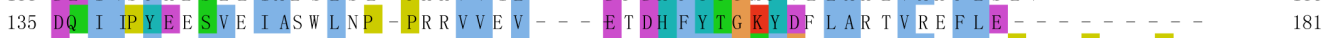
153 DDV ADAAAV ADR - - AREFEQSVVEL- - EADHFFVGQAGKVADRVAEFVPWVRPEASP 158 D T T V DW E P IVEL - - AGERGD ET TAL - - AG DH FLLGK HD E IASEVGRFFERTLLGSS - 150 DG TVDVEPVVDL - ATDRDDEVVS I - - PGDHFFVGQNETIAEHVSAFAAS RLFESGR

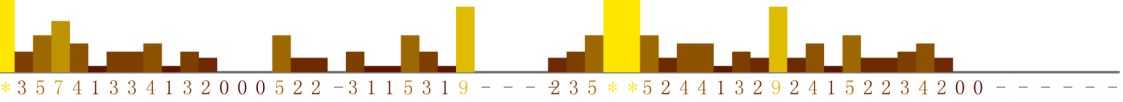

Figure S3. Multiple sequence alignment of the amino acid sequence of enzyme FS02 against selected alpha/beta hydrolase sequences from multiple archaea and bacteria (see Table S3). The corresponding amino acid numbers are given in right as well as left panel, and conserved positions are indicated by lower panel. This alignment was used for construction of the phylogenetic tree presented in Figure 1. 
$\begin{array}{llllllllllll}1 & 2 & 3 & 4 & 5 & 6 & 7 & 8 & 9 & 10 & 11 & 12\end{array}$

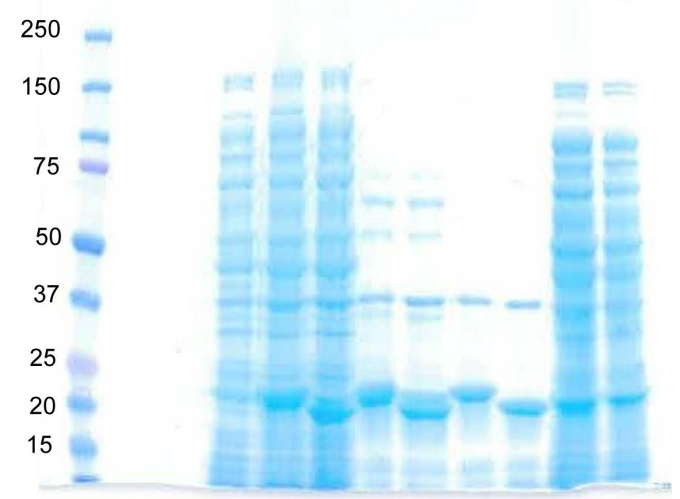

Figure S4. Verification of the production of enzyme FS02 as determined by (10\%) SDS-PAGE using sample from induced cultivation of E. coli BL21 (DE3) RELP (codon+) containing plasmids for expression of gene variants with and without a His6-tag. Lane 1, BioRad Dual Color Precision Plus standard (161-0374) kDa indicated; 2, extracellular fraction FS02-His6; 3, extracellular fraction FS02; 4, crude cell extract (CCE) pET16b; 5, CCE FS02-His6; 6, CCE FS02; 7, CCE FS02-His6 incubated $65^{\circ} \mathrm{C} 25$ minutes; 8, CCE FS02 incubated $65^{\circ} \mathrm{C} 25$ minutes; 9, CCE FS02-His6 incubated $80^{\circ} \mathrm{C} 30$ minutes; 10 , CCE FS02-His6 incubated $80^{\circ} \mathrm{C} 30$ minutes; 11, CCE FS02-His6 non-induced; 12, CCE FS02 non-induced. Molecular mass of FS02 with and without His6-tag is 23.4 and $21.2 \mathrm{kDa}$, respectively. SDS-PAGE analysis of samples after incubation at elevated temperatures show FS02 thermal stability, and visualizes the heat-based "purification" of the enzyme.

\section{Submit or recommend next manuscript to SCIRP and we will provide best service for you:}

Accepting pre-submission inquiries through Email, Facebook, Linkedin, Twitter, etc A wide selection of journals (inclusive of 9 subjects, more than 200 journals)

Providing a 24-hour high-quality service

User-friendly online submission system

Fair and swift peer-review system

Efficient typesetting and proofreading procedure

Display of the result of downloads and visits, as well as the number of cited articles

Maximum dissemination of your research work

Submit your manuscript at: http://papersubmission.scirp.org/ 